\title{
Ke spolupráci Antonína Heythuma s Karlem Hugo Hilarem a Karlem Dostalem v Národním divadle
}

Vlasta Koubská

\begin{abstract}
Abstrakt
Text je věnován spolupráci scénografa Antonína Heythuma s režiséry Národního divadla Karlem Dostalem a Karlem Hugo Hilarem mezi lety 1924 až 1936. Připomíná jak známé inscenace, tak upozorňuje na jejich připravované projekty, které se z rưzných příčin neuskutečnily. Dále popisuje scénografưv zásadní vklad do moderní české scénografie, který souvisel s konstruktivistickými a funkcionalistickými myšlenkami, bravurní prostorotvornou aplikací paravánového systému nebo s využitím fotografické či filmové projekce. Nové poznatky vycházejí vesměs z dosud neznámých pramenů.
\end{abstract}

\section{Klíčová slova}

scénografie, divadlo, umělecká avantgarda, umění tzv. První republiky, Národní divadlo Praha, Antonín Heythum, Karel Hugo Hilar, Karel Dostal

\begin{abstract}
The article is focused on the cooperation of stage director Antonín Heythum and the directors of the National Theatre, Karel Dostal and Karel Hugo Hilar around 1924-1936. It mentions both famous productions as well as projects that were planned, but for various reasons never performed on stage. It proceeds with outlining the scenographer's contribution to modern Czech scenography, which was connected to the constructivist and functionalist ideas, outstanding space-forming application of screen system, or usage of photographic or film projections. New findings are mostly based on hitherto unknown sources.
\end{abstract}

\section{Key words}

scenography, theatre, art avantgard, art in the First Republic, National Theatre Prague, Antonín Heythum, Karel Hugo Hilar, Karel Dostal 
Informace, které jsme dosud o scénické tvorbě Antonína Heythuma měli, se opíraly vesměs o několik článků, slovníkových hesel a o návrhy ze scénografické sbírky divadelního oddělení Národního muzea ${ }^{1}$ a materiály ze sbírky architektury Národní galerie. ${ }^{2}$

Chystaná monografie o Antonínu Heythumovi, kterou píše Vlasta Koubská a kapitolu o architektuře a nábytkářské tvorbě připravuje Radomíra Sedláková, bude založena především na nově objevených soukromých pramenech a archiváliích uchovávaných na území USA, kde Heythum žil od roku $1939^{3}$ do roku 1954, kdy zemřel v německém Rottachu-Egern. Stalo se tak po jedné z poznávacích cest po evropských architektonických památkách, které organizoval pro americké studenty. ${ }^{4}$ Následující text se zabývá Heythumovou tvorbou pro Národní divadlo a je zacílen na spolupráci s režiséry Karlem Dostalem a Karlem Hugo Hilarem, protože právě k ní byly nalezeny nejzajímavější doklady. Jde nejen o materiály zachycující umělecké snahy, ale též o doklady týkající se finančních otázek.

Scénografova práce v Národním divadle se vázala celkem ke dvaatřiceti inscenacím, z nichž některé výrazně zasáhly do vývoje moderní scénografie, jiné byly připravovány, ale nakonec nebyly realizovány. Během dvanácti a půl roku Heythum zrealizoval šestnáct inscenací s režisérem K. Dostalem, s K. H. Hilarem k premiéře dovedl pouze dvě inscenace, pět inscenací provedl s Vojtou Novákem (Slabé pohlaví, Let královny, Záhadný připad, Tančici safír, Továrnik Dodsworth), jednu inscenaci dokončil s režisérem Viktorem Šulcem (Todo je outsider), jednu s Jíŕím Frejkou (Lásky hra osudná) a zrealizoval jeden balet (Nikotina) s choreografkou Jelizavetou Nikolskou. ${ }^{5}$

Spolupráce Antonína Heythuma s Národním divadlem začala v roce 1924, tedy v době, kdy Heythum v Praze studoval pozemní stavitelství. ${ }^{6}$ Teprve později vznikly

1 Sbírka čítá 114 scénických a kostýmních návrhů k 26 inscenacím. Většina z nich pochází z výstavy, kterou Heythum připravil o vlastní tvorbě v Uměleckoprůmyslovém muzeu Obchodní a živnostenské komory $\mathrm{v}$ roce 1935.

2 V zář́i roku 2018 byla otevřena v Galerii moderního umění v Roudnici nad Labem komorní výstava, která v základních rysech seznámila návštěvníky s Heythumovým dílem, katalog k ní rovněž vycházel hlavně ze zmíněných zdrojů a připravili jej Vojtěch Poláček, Jakub Potůček a Vendula Potůčková Jurášková (HEYTHUM 2018), výstava byla věnována divadelní, architektonické a nábytkářské práci umělce.

3 V prosinci 1939 ratifikovali správci Rockefellerovy nadace válečný program, který usiloval o udržování kontaktů s evropskými vědci a univerzitami, a rozšriŕili úsilí Rockefellerovy nadace o záchranu evropských vědců, která byla zahájena v roce 1933. Na začátku roku 1940 získal Heythum finance na obživu z Emergency Program for European Scholars z této nadace a pobíral je až do roku 1945. Na sklonku roku 1938 a v roce 1939 pracoval na československém pavilónu pro světovou výstavu New York World's Fair 1939. Zároveň spolupracoval s manželkou na dokončení interiérů výstavního pavilonu Československa na San Francisco Golden Gate International Exhibition. Oba se stali členy výzkumné skupiny Fair Survey Group v Buffalo Museum of Science, kterou sponzorovala Rockefellerova nadace.

4 Většina nových informací bude publikována až v monografii, jejiž dokončení je naplánováno na rok 2021, kdy budeme vzpomínat 120. výročí umělcova narození. K tomuto období viz (KOUBSKÁ 2018).

5 Úplný soupis inscenací, na nichž A. Heythum pracoval jako scénograf pro Národní divadlo, je uveden na konci studie.

6 Po maturitě, kterou vykonal 12. června 1919 na Zemské vyšší reálce v Moravské Ostravě, začal studovat obor pozemní stavitelství na České vysoké škole technické v Praze, která se od 1. září 1920 organizačně změnila na České vysoké učení technické, studoval také Vysokou školu architektury a pozemního stavitelství. Školu dokončil vzhledem k prodělanému závažnému onemocnění tuberkulózou až 1. června 1934 závěrečným projektem u prof. Dr. Antonína Mendla na téma Obchodní hotel. 


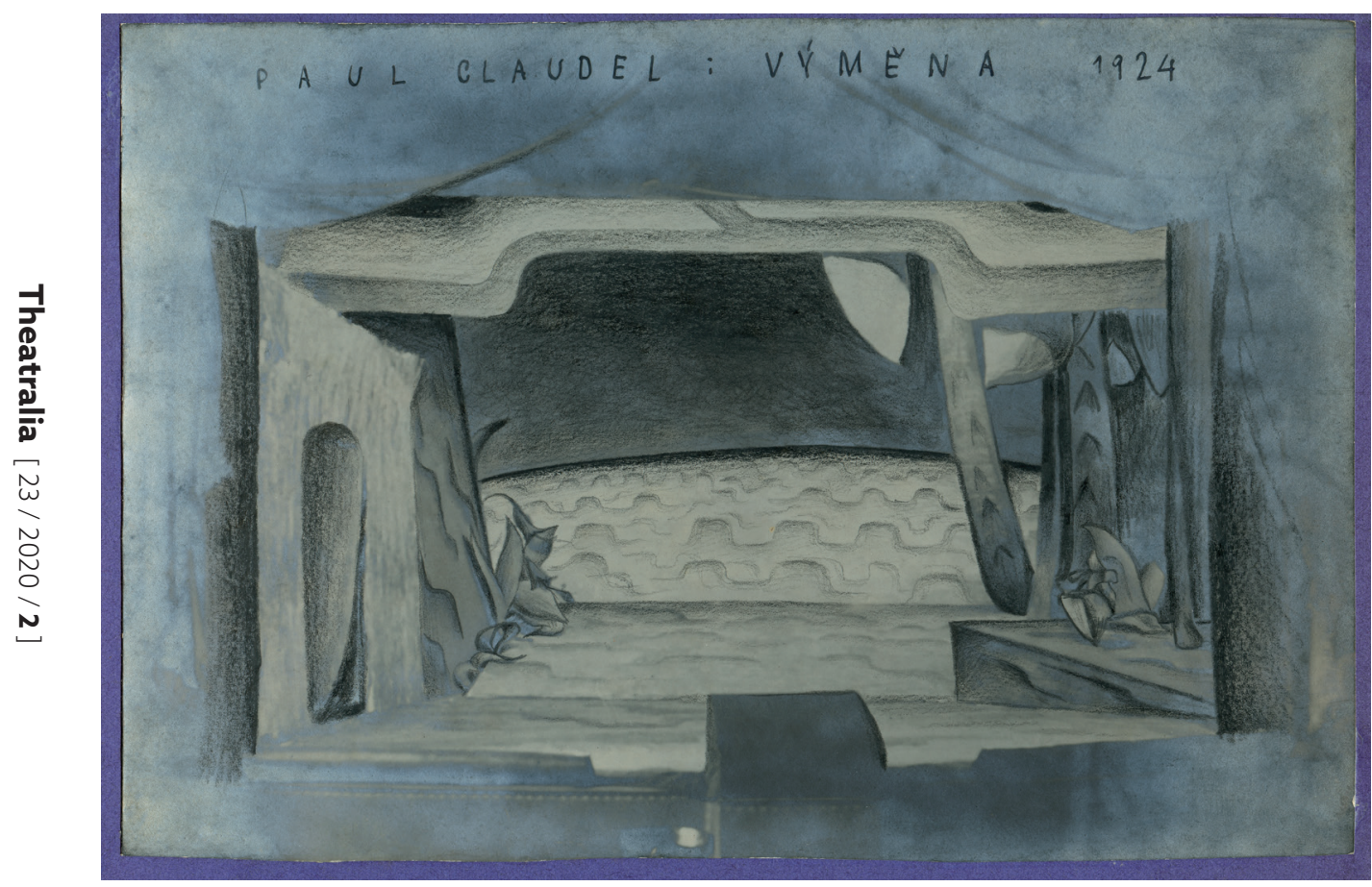

Obr. 1: Návrh scény. Výměna. 1924. Soukromá sbírka.

jeho nejznámější avantgardní inscenace, v nichž uplatnil odhalené dřevěné konstrukce, díky kterým bývají dávány do souvislosti s konstruktivismem. ${ }^{7}$

Tehdy měl za sebou př́ípravu sedmi inscenací v Moravské Ostravě (Poštovni úřad, Tři původni aktovky, Svatopluk, Liják, Amfytrion, Danton, Námluvy Pelopovy), ${ }^{8}$ připravoval jednu inscenaci v pražském Švandově divadle (Jarni mámeni - nerealizováno), chystal scénografii pro inscenaci v sále pražské Konzervatoře (Výměna) a připravoval též inscenaci Wolkerovy Nemocnice (nerealizováno). Na jaře roku 1924 přišla první nabídka z Národního divadla od jednoho z šesti kmenových činoherních režisérů naší první scény Jaroslava Hurta na vytvoření výpravy pro Andrejevův Rozum. Hurt Heythuma objevil díky inscenaci Claudelovy Výměny, která byla výstupní zkouškou absolventů dramatické školy, kterou vedl právě sám profesor Hurt. Heythum pro tuto inscenaci v režii Josefa Schettiny využil scénografii, která byla doslova dílem jeho rukou. Nejen, že abstraktní výpravu pro „východní přímoří Ameriky“ navrhl, ale objekt sbil z latí, stříhal a šil látky, maloval i stavěl dekorace (ŠVEHLA 1971). Hurt během zkoušek v Heythumovi objevil velký talent a vzápětí jej přivedl do Národního divadla.

7 Pojištěni proti sebevraždě, Cirkus Dandin (1925), Když ženy něco slaví, Němý kanár, Depeše na kolečkách (1926).

8 Skutečně zrealizován byl pouze Amfytrion, premiéra 25. ledna 1923. 
Připomeňme v krátkosti, kteří moderní scénografové $\mathrm{v}$ této době v Národním divadle působili. František Kysela vypravoval výlučně operní inscenace často v tzv. „národním stylu“. Třebaže byla během roku 1924 u př́ležitosti 100. výročí narození Bedřicha Smetany vyhlášena soutěž na nové výpravy Smetanových oper, které se na výzvu Národního divadla zúčastnili ještě Vlastislav Hofman a Bedřich Feuerstein, jehož návrhy měly novou, čistou, purismem ovlivněnou a skutečně progresivní formu, přesto se ke zmíněnému výročí realizovaly dekorativní, umírněně moderní návrhy Kyselovy. Až po roce 1925, nejspíše též pod vlivem výstavy dekorativních umění v Paříži, opustil Kysela tento styl a ve své scénické tvorbě začal směřovat ke stylu dnes nazývanému souhrnně art deco. Ke konci roku 1924 B. Feuerstein vypravil puristicky lyrickou operu Rudolfa Karla Ilseino srdce (premiéra 11. 11. 1924). V činohře Vlastislav Hofman realizoval kubisticky ovlivněnou hru Chastelard (premiéra 20. 2. 1924) a Vinu (premiéra 2. 5. 1924) a Josef Čapek navrhl svým jedinečným maliřským způsobem s tvarově i barevně výraznými kostýmy a maskami inscenace Tartuffe (premiéra 4. 11. 1923) nebo Prostopášnik pan Le Trouhadec (premiéra 4. 3. 1924). K těmto divadelně-výtvarným moderním počinům se začal připojovat svým dílem také mladičký třiadvacetiletý Antonín Heythum. S některými progresivními inscenacemi v Národním divadle byl obeznámen, na základě osobních skicářů můžeme doložit, že navštívil nap̌r. inscenace Ohnivý buben (E. Prampolini, premiéra 20. 12. 1922), Země mnoha jmen (J. Čapek), ${ }^{9}$ Prodaná nevěsta a Dalibor (F. Kysela) ${ }^{10}$ nebo Istar (B. Feuerstein) ${ }^{11}$ Studoval rovněž nejmodernější sovětskou scénografii, což dokládají detailně provedené kresby scénografie Alexandry Exterové pro Romea a Julii nebo pro Vesninovy inscenace Vzkř̌̌šení či Faidra. ${ }^{12}$

První inscenací, kterou vypravil Heythum v Národním divadle, byl tedy Rozum (Lev Nikolajevič Andrejev, 15. 5. 1924, režie Jaroslav Hurt). Zachovaný dvojnávrh scény je vytvořený axonometrickou perspektivou (NM D 553) ${ }^{13}$ kterou ve svých návrzích využíval Heythum jen zřídka. V komentáŕích, které se nachází na dalších scénických skicách, popsal sám scénograf velmi pečlivě barevnost jednotlivých scén, jejichž valérové tóny a citlivě osvícené rekvizity se vesměs odrážely od temného pozadí nebo černého nekonečného sametového horizontu. Již v této rané inscenaci se projevila Heythumova schopnost vytvořit světelně působivou jevištní atmosféru. Pečlivě popisoval barevnost stěn, stínidel, koberců a intenzitu osvětlení, aby vyjádřil intimní šerosvitné scénické okamžiky. Využil rozměrný závěs pro zakrytí objektu vysoké klece. Pracoval s principem nárožního postavení stěn, aby dosáhl nezvyklého úhlu pohledu na scénickou stavbu. Umně prohloubený prostor úzké chodby s řadou dveři do pokojů psychiatrické léčebny byl sevřen velkoplošným oknem a stěnou, aby působil stísněně a doslova nekonečně. Kostýmy navržené tušovou kresbou kolorovanou akvarelem vycházely z civilního oděvu

\footnotetext{
9 Navštíveno 10. dubna 1923 (scénografie J. Čapek).

10 Opery navštíveny v létě 1923 a v dubnu 1924.

11 Navštívena 2. listopadu 1924.

12 Skicáře v soukromé sbírce, sovětské scénografie nejspíše vytvořeny na základě fotografií.

13 Dříve axonometrickou projekcí navrhl ještě nerealizované Jarni mámeni pro Švandovo divadlo (NM D 24218-24332). Existuje ještě program Zkušebni scény, kde konstrukci pro scénu Cirkusu Dandin Heythum nakreslil touto metodou.
} 


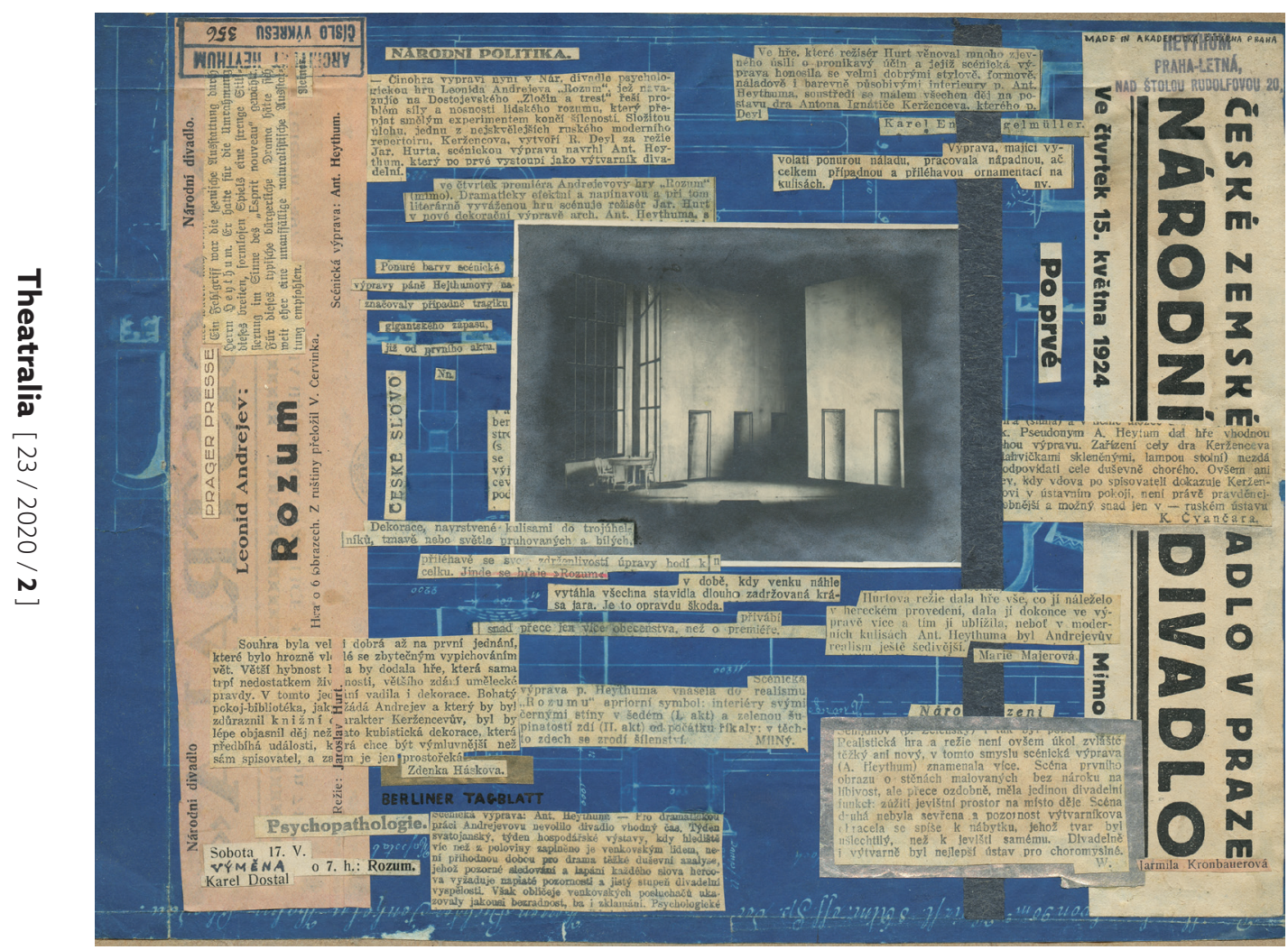

Obr. 2: Rozum. Koláž Obraz pýchy. 1924. Soukromá sbírka.

(Soukromá sbírka). ${ }^{14}$ Sám scénograf vytvořil v roce 1924 z fotografie scény a novinových kritik koláž, kterou nazval Obraz pýchy. ${ }^{15}$

Na začátku další divadelní sezóny začal Heythum spolupracovat s Karlem Dostalem. První jejich společnou inscenací byl Hilbertův Druhý břeh (20. 11. 1924), v jehož textu vystupovala do popředí potřeba svědomí a nalezení Boha. ${ }^{16}$ Zachovaný návrh s půdorysem prokazuje Heythumovu snahu po prohloubení hracího prostoru pomocí zalomení dvou jevištních stěn směřujících do jednoho rohu (NM D24035). Tím scénograf nejen vtipně evokuje úběžníkovou perspektivu historicky využívanou v malířské scénografii, ale navíc pomocí nárožně postavených dějišt s nábytkovou sestavou vnáší do soudobého interiéru dynamiku a napětí. Paravánový princip vymezování hracího prostoru

14 Zde také doklad o zaplacení honoráře 600 Kč (7. 4. 1924).

15 Koláž se nyní nachází v soukromé sbírce. Z roku 1924 známe ještě Heythumovu koláž Underground (SVRŠEK 1924).

16 Inscenace Druhý břeh byla po jedenácti letech na scéně Národního divadla v Heythumově scénografii a v režii Karla Dostala znovu obnovena při příležitosti Sjezdu českých katolíků. Její klíčové téma konfliktu moderní společnosti s vírou, svědomím a vinou bylo pocitováno v republice nově ohrožované nacismem jako nadmíru aktuální. 
Heythum později ve své tvorbě rozvinul tak, že nechával vyznít umně zalomené prostory, fungující jako potřebná paralelní dějiště, ale vnímané jako přirozená součást jednoho dramatického prostoru. Moderní vkus a mladistvou energii evokovala skvěle uplatněná silná vodorovná modrá prolamovaná linka na stěnách, která kopírovala půdorys celé jevištní stavby. Vysoká okna otevírala zadní prostor za kulisou, aby scénu nejen opticky prohloubila, ale vnesla do ní vědomí dalšího emocionálního rozměru. ${ }^{17}$

V náboženským mysticismem prodchnuté inscenaci Přriští Mesiáš (Henry Soumagne, 5. 1. 1925, režie Karel Dostal), která vyvolala ve společnosti velkou polemiku a po jednom představení byla především z důvodů relativizace a zpochybnění morálních hodnot censurou zakázána, ${ }^{18}$ vyřešil scénograf vskutku důmyslně hlavní hrací prostor. Ústřední příběh odehrávající se během štědrovečerní noci ve sklepním prostoru varšavské nálevny byl lokalizován na jevištní podlahu, ale prostor byl vertikálně rozehrán hlavně centrální čistou konstrukcí s výraznými schodišti. Prostorově vyřešený vchod s polským nápisem WODKA a rádoby hebrejským ekvivalentem nejen umně dynamizoval prostor, ale hlavně upozorňoval na exteriér ulice. Pod její úrovní, tedy ve sklepě, se odehrávalo magické noční snové setkání, v němž se zjevovala božstva světových náboženství: Buddha, Usir, Jupiter a Zeus, Alláh, Mohamed, Jehova nebo Kristus. Výtvarně působivá byla nejen patina sklepního zdiva, které bylo seskládáno a vrstveno několika řadami různě dlouhých šál, ale také tři rozestavěné stoly s židlemi $\mathrm{z}$ ohýbaného dřeva, ${ }^{19}$ nálevní pult a spoře svítící nejlevnější plechové lampy (NM D 21771) ${ }^{20} \mathrm{~V}$ programu stálo uvedeno: „[...] Konstruktivism je heslem nejmoderněǰší realizace [...]“ (AND: Program $\mathrm{k}$ inscenaci).

První spolupráce s režisérem Karlem Hugo Hilarem na inscenaci Veselé ženy windsor$s k e^{21}$ nebyla nikdy dovršena skutečnou divadelní realizací (stejně jako i další dva připravované projekty Hra o lásce a smrti a Žebrácká opera). Zachované tužkové zápisky a skici se týkají přesné charakterizace dramatických postav i představ o scénografii. Skicář z roku 1925 obsahuje přesné rozkresy pěti jednání s celkově třiadvaceti scénami (Soukromá sbírka).

Zde počítal Heythum s abstrahovanými scénickými objekty-konstrukcemi: transparentní dům u Pacholíků měl být vystaven z latí tak, aby bylo vidět dovnitř, okna byla naznačena opěrnými lištami ve výši parapetů. Důležitou roli pak měly hrát schody, promítané nápisy i nejobyčejnější typy rekvizit (sklenice s uchem, žárovky se stínidly, lahvička inkoustu), které měly kontrastem k abstraktní scénické stavbě podpořit komiku figur. Heythumova poznámka „prohlédnout konstrukci jeviště a využít technických

17 Za inscenaci Druhý břeh žádal A. Hetyhum v dopise z 20. listopadu 1924 honorář 1000 Kč (Soukromá sbírka).

18 Ke známé kauze přípravy, cenzurních zásahů a inscenování Př̌̌stího Mesiáše naposledy např. (BRDEK 2014: 253-265). Na výjimečné povolení byl Nový Mesiáš ještě jednou inscenován ve značně „umírněné“ podobě 21. ledna 1925 .

19 V realizaci nakonec využit pouze text WODKA bez „hebrejského“ textu a jednoduché rovné židle.

20 Honorář činil 1500 Kč (Soukromá sbírka, Dopis K. H. Hilara ze dne 24. 11. 1924).

21 Kresby vytvořeny v období červenec-srpen 1925 (Soukromá sbírka), skicář vznikl na reversu starého německého denního kalendáře z roku 1924. 


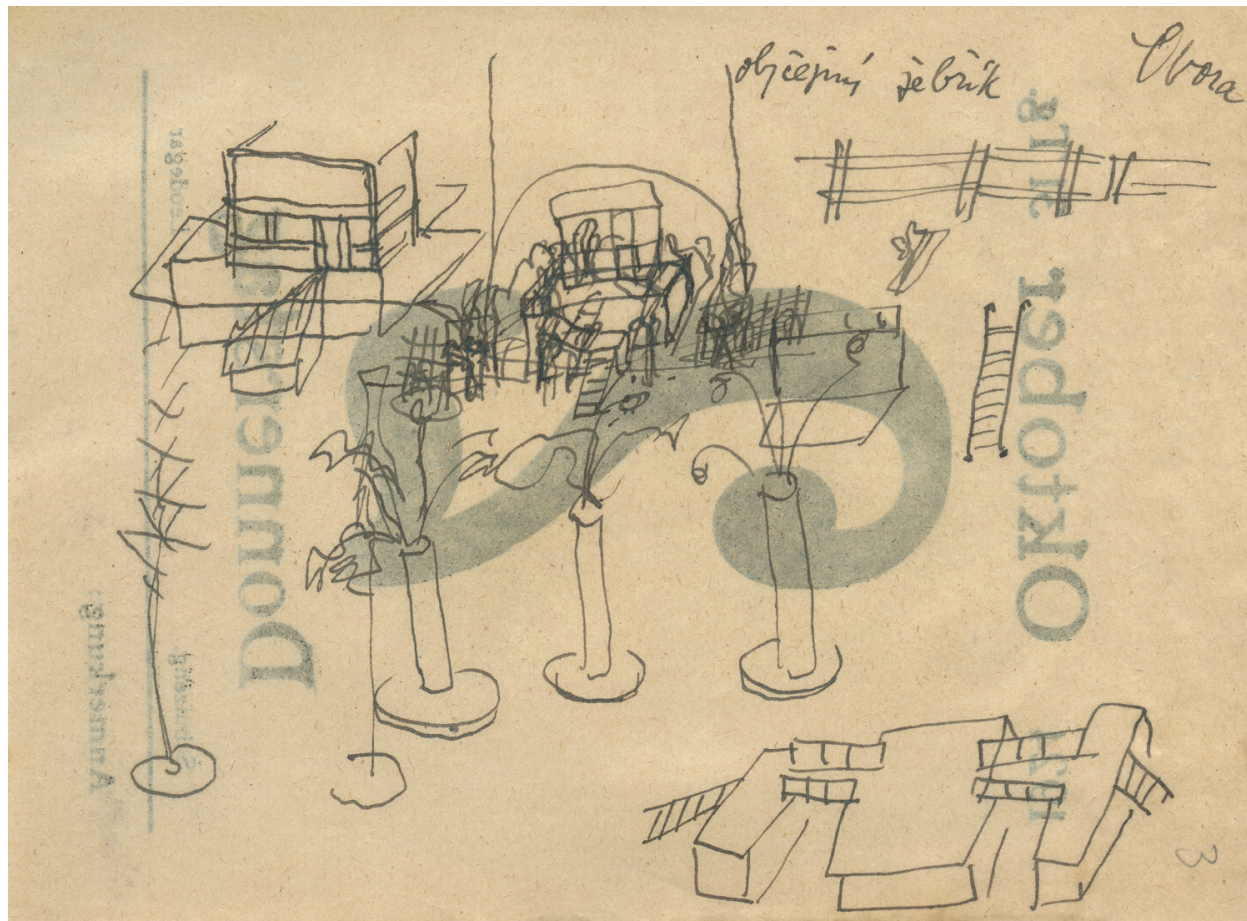

Problém oboy! Mun'to gt nèco tajenumetes,

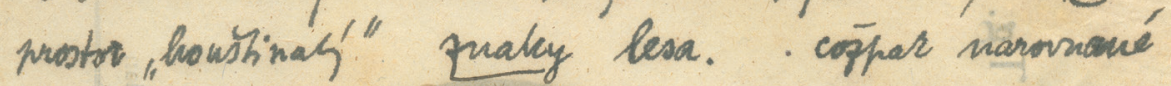

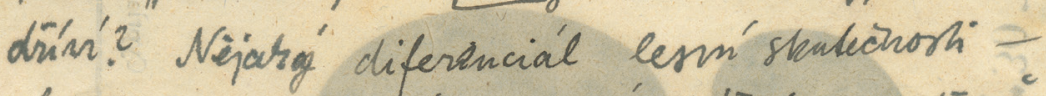

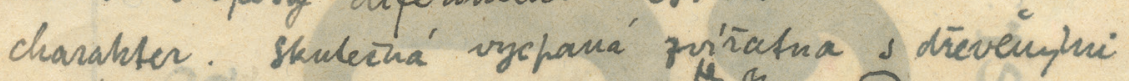
podtawechy hadi.

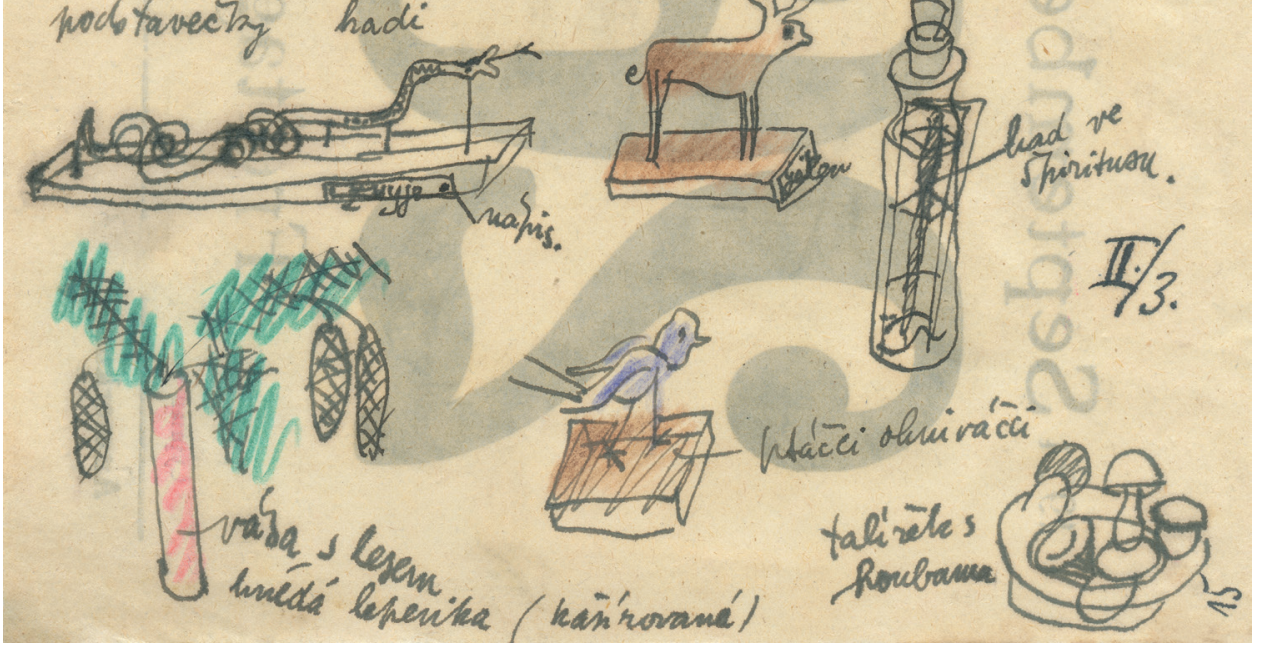

Obr. 3 + 4: Tužkové zápisy a skici. Veselé ženy windsorské. 1925. Soukromá sbírka. 


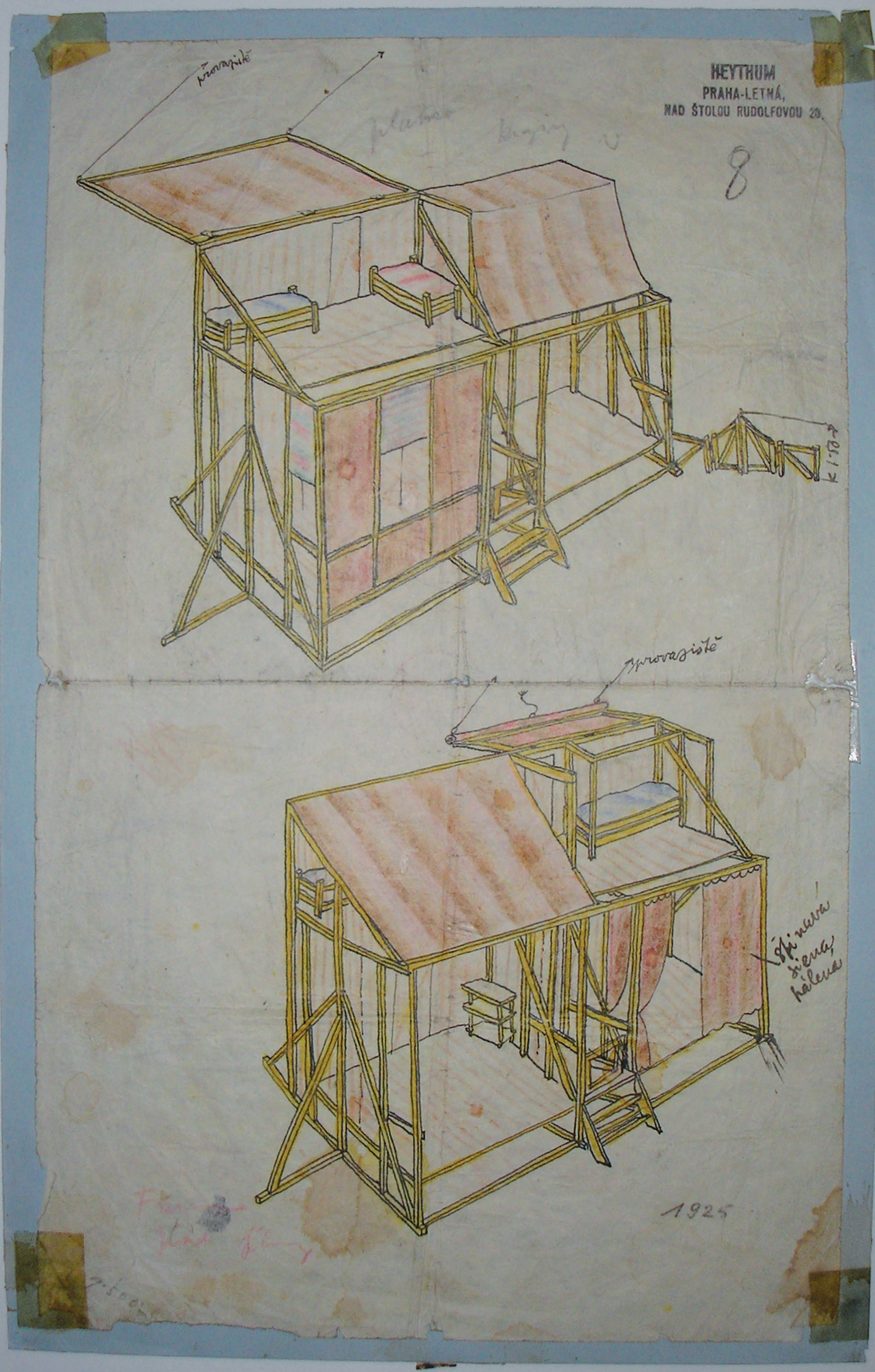

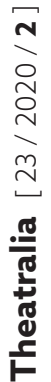

Obr. 5: Návrh scény. Farma pod jilmy. 1925. NM S-VIla-6b_D 21.799 
vymožeností k měnění definitivně vystavěných scén“ prokazuje jeho úmysl rychle proměňovat jevištní stavbu. Kresba i poznámka ke scéně windsorské obory naznačuje, že měla být postavena ze tří souběžných praktikáblů, přes které ležely běžné žebříky, a „zřízenec divadla [...] může před začátkem scény rozsypávat písek (jako se to dělá na ulicích)“. Tato scéna měla být doplněna „vázovým stromořadím“22 s poznámkou „především žádná perspektiva a sekundárně vyloučena jakákoliv perspektivní iluse!“ Ironii do celé scény měla vnášet vycpaná zvířata s dřevěnými podstavečky, had ve špiritusu, taliřky s kašírovanými houbami. Heythumovy vpisky přesně popisují, jak měla scéna působit na diváky: „Musí to být něco tajemného, prostor ,houštinatý, znaky lesa, cožpak narovnané dříví? Nějaký diferenciál lesní skutečnosti [...]“(Soukromá sbírka). Můžeme jen litovat, že ironické vyznění scény nakonec na scéně nebylo nikdy uskutečněno.

Farma pod jilmy (E. O’Neill, Stavovské divadlo, 3. 10. 1925, režie Karel Dostal) naopak vstoupila do dějin scénografie jako jedna z nejranějších ukázek „konstruktivistického“ scénického objektu, který odhaluje jevištní stavbu (NM D 21799-801). Jde o zajímavou a nesporně progresivní ukázku nového vnímání jevištního objektu, avšak s konstruktivismem sovětského typu má pramálo společného. Nejpodstatnější je, že svou kompozicí evokuje tvarově i prostorově farmářský srub. Tím se však jen z části vyhýbá iluzivnosti a jeho ztvárnění doplněné řadou realistických rekvizit souvisí mnohem více s poetismem než s mašinismem ruského typu. ${ }^{23}$ Určitý stylový rozpor byl zachycen již v soudobém tisku, kde se hovoří o tom, že scéna je vytvořena „po ruském vzoru“, ale „úprava scény odpovídá surovému naturalismu hry“ (Právo Lidu 11. 10. 1925: 3).

V souvislosti s konstrukcemi využívanými Heythumem je třeba připomenout skutečnost, že studoval na Českém vysokém učení technickém také obor lodních konstrukcí, jistě též proto si s dřevěnými konstrukcemi podobného typu uměl lehce poradit. Zároveň byl evidentně seznámen s inscenací, která byla uváděna na Broadway v New Yorku. ${ }^{24}$ Vlastní scénografovy podrobné tušové kresby s rozfázovanými proměnami scénické stavby zobrazující abstrahovaný farmářský domek mají popisku psanou Heythumovou rukou „The Cohan Theatre, Broadway 43 ${ }^{\text {rd }}$ Street (8. 7. 1925)“ (Soukromá sbírka). ${ }^{25}$ Důmyslná variabilita newyorského scénického řešení scénografa nejspíše mohla inspirovat $\mathrm{k}$ dnes již proslulému řešení, jež využívalo především rychlého zakrývání a odhalování jednotlivých dějišt pomocí závěsů a rolet v lomené barvě sieny pálené. ${ }^{26}$ „Konstruktivistické“ řešení odhalené „kostry“ objektu pak mohlo být originálním scénografovým nápadem. Zdá se totiž, že jde o velmi blízkou variantu zamýšlené stavby domu „u Pacholíků“ z připravovaných Veselých žen Windsorských.

Bohužel ani druhá inscenace připravovaná roku 1925 ve spolupráci s režisérem K. H. Hilarem se nedočkala finálního provedení. Rollandova Hra o lásce a smrti měla

22 Opravdu ve velkých vázách umístěnými stromy.

23 Podle dopisu z 9. ř́ijna 1925 obdržel Heythum za inscenaci Touha pod jilmy (později nazvaná Farma pod jilmy) honorář 700 Kč, původně požadoval 1500 Kč (Soukromá sbírka, Dopis ze 14. 9. 1925).

24 V období od 11. listopadu 1924 do 17. ř́ijna 1925.

25 V této době byla Farma pod jilmy v Cohan Theatre inscenována a pro velký úspěch na různých scénách na Broadway dosáhla 420 představení.

26 Viz návrh (NM D 21799). 


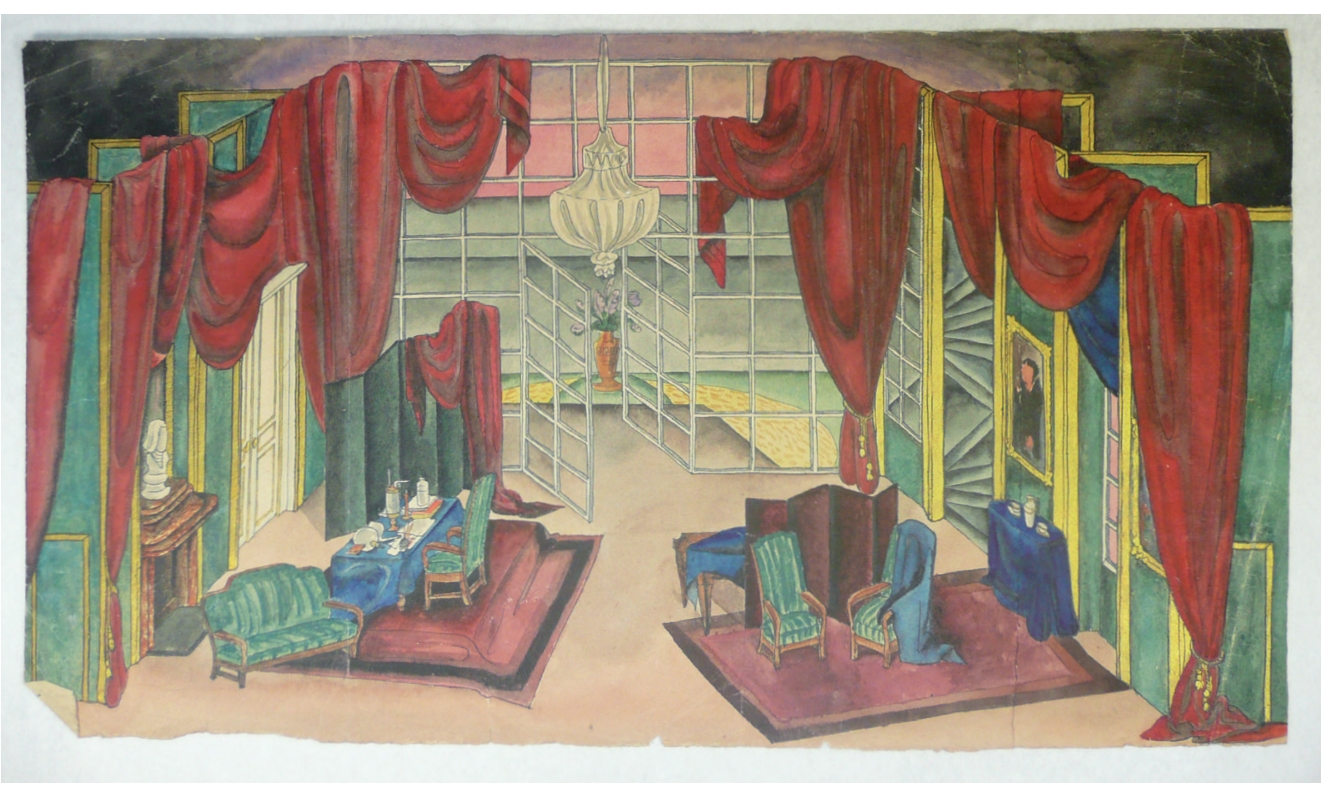

Obr. 6: Návrh scény. Hra o lásce a smrti. 1925. NM S-VIla-6i_D 1593.

být nejprve jejich společným dílem, avšak v ř́jnu roku 1925 si Heythum do jednoho ze svých deníků zapisuje: „6. X. 1925 vzdal jsem se spolupráce s Národním divadlem, vrácení výpravy Rollandovy Hry o lásce a smrti režisérovi Dr. K. H. Hilarovi z ideových důvodů." Nebyly tak znovu uplatněny ani existující skici ke scénám ani kostýmní návrh pro postavu Curvoisiera, kterou měl hrát Václav Vydra st. ${ }^{27}$

Přesto je více než jasné, že Heythum vedl s Hilarem několikeré konzultace ohledně této hry, nebot existují tužkové skici, v nichž lze nalézt rukopisy obou umělců. Ze skic lze vyčíst, jak měly vypadat salónní scény, v jejichž sevřeném prostoru měla hrát nejdůležitější roli bohatá drapérie. Na cedulích z 12. prosince 1925, kdy se konala premiéra Hry o lásce a smrti, je jako autor scény uveden Karel Hugo Hilar a jako výtvarný spolupracovník Vlastislav Hofman, přestože realizovaná scéna nese jasné stopy Heythumova prostorotvorného rukopisu zvláště v kombinaci tří párů plných bočních kulis s centrální lehkou prosvětlenou žalářní konstrukcí.

Scénografii pro balet Zmatek (Darius Milhaud, 21. 5. 1926), který režíroval F. Pujman v choreografii Remislava Remislavského, zde zmiňuji výjimečně, ačkoliv nebyl režírován ani Hilarem ani Dostalem. Jde totiž o brilantní ukázku čisté práce s paravánovými stěnami. Přesnosti a jasnosti vymezeného baletního prostoru pro tanečníky napomáhá nejen jednoduše působící kultivované členění, ale především odkaz na barokní perspektivní iluzivní kulisy. Pozoruhodné valérové barevnosti mohlo být docíleno nejspíše barevným svícením (NM D 24043). ${ }^{28}$

27 Skici i kostýmní návrh (Soukromá sbírka).

28 K této inscenaci se vztahují dva dopisy, které dokládají mírné posunutí termínu realizace inscenace (Soukromá sbírka). 
Pokud jde o prvních pět realizovaných inscenací uvedených v Národním divadle, patří zvláště Přišti Mesiáš, Farma pod Jilmy a Zmatek ke scénograficky skutečně progresivním inscenacím, které na tuto scénu přinesly výrazně abstrahované ztvárnění scénického prostoru, jenž byl formulován poměrně jednoduchými, avšak velmi působivými prostředky. Je třeba si uvědomit, že například avantgardní Zelenkovy a Hilarovy inscenace Shakespeara Jak vám se to líbi nebo Blažena a Beneš jsou datovány až rokem 1926.

Antonín Heythum měl již od dětství poměrně chatrné zdraví, často trpěl angínami a chorobami dýchacích cest, ${ }^{29}$ koncem května roku 1926 se jeho zdravotní stav velmi zhoršil a byla mu diagnostikována tuberkulóza. Ve vážném stavu byl odvezen do Vysokých Tater a léčen v sanatoriu v Tatranské Poliance, tedy na tomtéž místě, kde se nedlouho před tím neúspěšně léčil Heythumův přítel Jiří Wolker. ${ }^{30}$

Přátelství obou mladých mužů vzniklo evidentně nejen jejich společným členstvím ve skautské organizaci Junák, ${ }^{31}$ ale i členstvím v Devětsilu. Když Wolker zemřel, zapsal si Heythum do svého deníku: „Nejdražší přítel a básník Jiří Wolker zemřel nebylo mu ještě 24 roků. Jeho odchod způsobil mnoho bolesti."32 Zachované dopisy navíc dokumentují Heythumovu snahu zorganizovat v Praze večer Wolkerových veršů (Soukromá sbírka, Dopis z 6. 4. 1924) nebo snahu o jejich zhudebnění (Soukromá sbírka, Dopis z 8. 4. 1924).

Z Tatranské Poljanky, kde byl Heythum ubytován na několika různých místech, ${ }^{33}$ pokračoval v léčení v sanatoriu Paseka ${ }^{34}$ nedaleko Olomouce, kam se za ním několikrát vydali jeho umělečtí kolegové. Existuje dokonce fotografie, na níž je A. Heythum zachycen s tehdejším režisérem olomouckého divadla Františkem Salzerem (Soukromá sbírka), s nímž během svého uzdravování realizoval patnáct inscenací v Českém divadle v Olomouci (Hra na zámku, Doňa Sanča, Chlupatá opice, Elektra, Smrt Hippodamie, Živouci mrtvola a další), v němž se uplatnil jako šéf výpravy.

29 Dokonce si Heythum jako jeden z vůdčích představitelů severomoravského Junáka sám pro sebe vytvořil „totem“ (jakousi vlastní značku), který vycházel z podoby jeho zduřelých a zanícených krčních mandlí. Mnohé výlety a akce skautů, které vesměs organizoval a pečlivě popisoval ve svém skautském deníku, skončily nachlazením, teplotami a ulehnutím na lůžko (Soukromá sbírka, Skautský deník).

30 Bývalé velké přátelství s Wolkerem bylo krutě ukončeno 3. ledna 1924, kdy básník na tuberkulózu zemřel. Známý Wolkerův epitaf „Zde leží básník, jenž miloval svět a pro spravedlnost jeho šel se bít. Dřív, než moh srdce k boji vytasit, zemřel mlád 24 let" nejen že vstoupil do dějin české poezie, ale stal se mementem celé mladé generace, která po první světové válce na tuto zákeřnou chorobu umírala a naděje na vyléčení byla mizivá. Heythum po smrti př́tele usiloval o to, aby byl Wolkerův hrob v Prostějově upraven podle jeho představ. O svém hrobu napsal básník v závěti: „Pochován chci býti v Prostějově, chci míti na hrobě malý vojenský březový kř́ž s nadpisem Jiří Wolker, spisovatel, 23(?) let." Toto básníkovo přání bylo Heythumem nejprve architektonicky navrženo a později s úctou zrealizováno (DURYCH 1930: 4, zde se nalézá rovněž průvodní zpráva o úpravě Wolkerova hrobu od Antonína Heythuma, str. 13 ad.).

$31 \quad$ Wolker od roku 1916.

32 Zápis je datován 2. ledna 1924, snad jde o dodatečný zápis, protože oficiálně Wolker zemřel až 3. ledna 1924 (Soukromá sbírka).

33 Doložen máme např. pobyt v červnu 1926 ve Vile Tivoli (Soukromá sbírka).

34 Přesné datum začátku jeho pobytu v sanatoriu Paseka neznáme, ale byl zde jistě v červenci 1927 (do května 1929). 


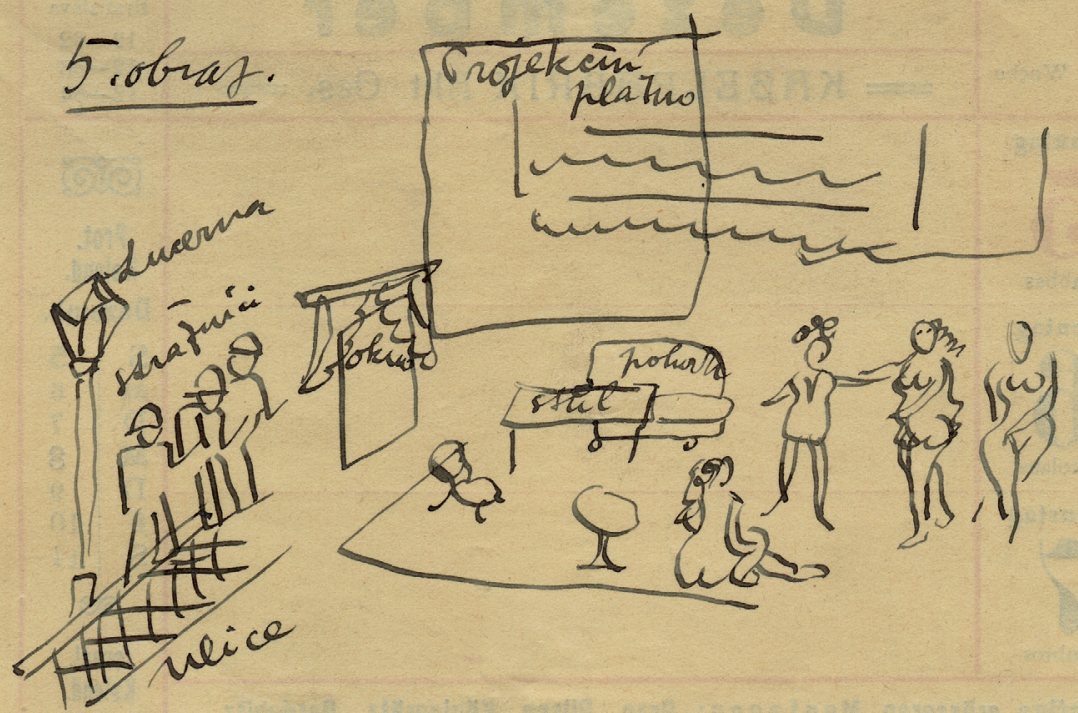

Obr. 7: Návrhy scény. Žebrácká opera. 1930. Soukromá sbírka. 


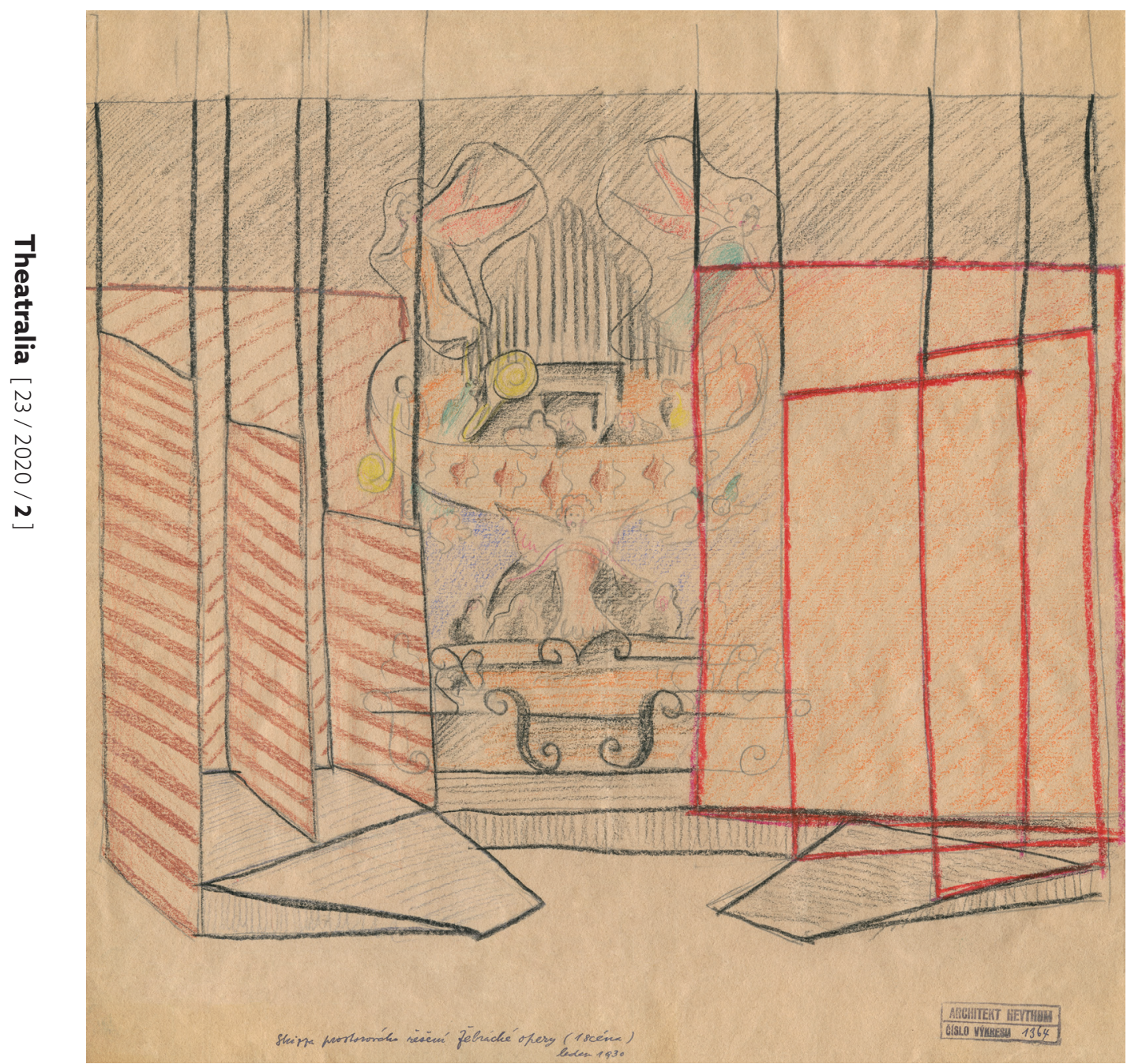

Obr. 8: Návrhy scény. Žebrácká opera. 1930. Soukromá sbírka.

Spolupráce s Národním divadlem v Praze se obnovovala jen velmi pozvolna, začala zřejmě na sklonku roku 1928 projektem Žebrácké opery (B. Brecht, K. Weill), kterou se chystal s Heythumem inscenovat znovu Karel Hugo Hilar. Existují tužkové skici, které jsou vesměs kresleny Hilarem s řadou popisek jednotlivých dramatických situací: „,...] žehlí, zrcadlo, mele se kafe, stoleček, čte noviny, zloděj, mytí schody, leží, čekání hosty [...]“. Rukou Heythumovou jsou nesporně navrženy obrazy 1 a 5 , na nichž scénograf počítal s využitím projekce. Na projekčním plátně se měly objevit reklamní nápisy nebo plán města Londýna, jinak mělo být plátno podsvíceno (Soukromá sbírka).

Skici dokumentují, že se konalo větší množství schůzek, na kterých si režisér se scénografem sdělovali detaily potřebné pro scénografickou vizi inscenace. Podle všeho 


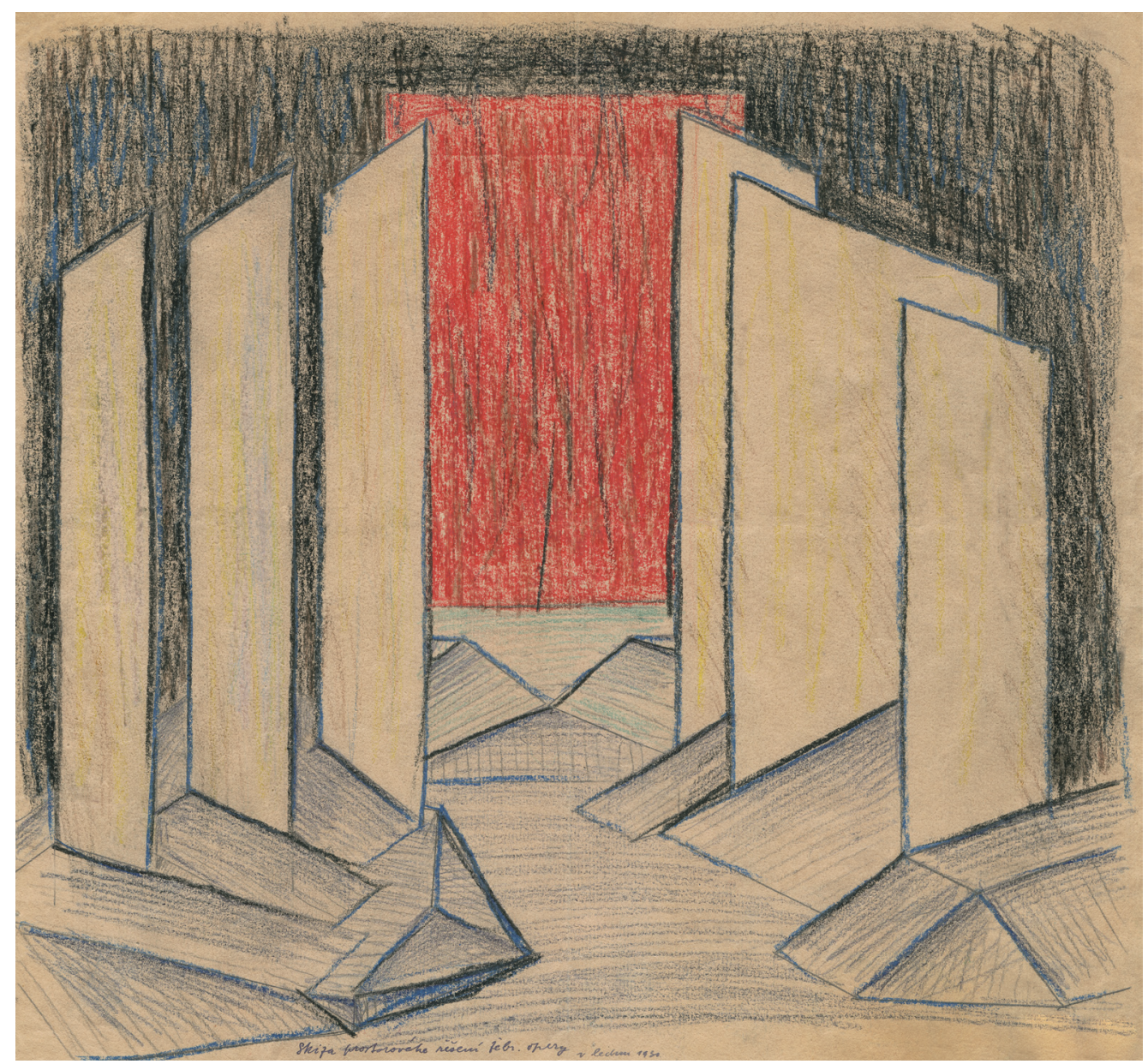

Obr. 9: Návrhy scény. Žebrácká opera. 1930. Soukromá sbírka.

to bylo v době, kdy Heythum pracoval jako šéf výpravy v Olomouci a za těmito schůzkami musel dojíždět do Prahy. Snad to byl obtížný zposob komunikace, snad to byly jiné události, které zatím neznáme, každopádně ke společné realizaci Žebrácké opery opět nedošlo, a to ani v následujících letech. K tomuto projektu se váží dva zachované dopisy z následujícího roku 1929, kdy se Heythum znovu přistěhoval natrvalo do Prahy, ${ }^{35}$ a zřejmě do této doby doufal a čekal, zda dojde k realizaci jím navržené podoby inscenace:

[...] Dovoluji si nesměle připomenouti, že jsem s Vámi dlouho pracoval na výpravě hry Žebrácká opera, která jak z letošního repertoiru vysvítá se v Národním divadle už dělat nebude. Vím, že i Vy jste do díla investoval mnoho energie, která se Vám rovněž nezrentovala realizováním hry na jevišti, prosím však, abyste mně nezazlil mé připomenutí, že mám téměř

Na novou adresu Nad štolou Rudolfovou 20. 
celou dekorační výpravu a že tedy i mně práce mnoha hodin zůstala neužitečnou, nežádám přímo o finanční náhradu za tuto práci, prosím Vás však snažně, abyste při nových hrách, které mně zadáváte, laskavě mne poněkud odškodnil mírným zvýšením honoráře. Doufám, že Vám tato prosba nezpůsobí žádných nepř́ijemností. Jelikož jsem opět již na trvalo v Praze, prosím Vás snažně o častější zaměstnání. Děkuji Vám za Vaši ochotu a jsem Vám zcela oddaný AH (Soukromá sbírka, Dopis A. Heythuma K. H. Hilarovi ze dne 4. 10. 1929).

Karel Hugo Hilar Heythumovi za deset dnů odpověděl:

„[...] otázka Žebrácké opery není ještě vyřízena v negativním smyslu, nicméně přes to budu dbáti toho, aby Vám byla nahražena škoda dosavadního prodlužování [...]“ (Soukromá sbírka, Dopis K. H. Hilara 14.10.1929)

Avšak ani v dalších dvou letech 1930-1931 se Žebrácká opera nerealizovala a Heythum znovu napsal Hilarovi dne 6. března 1931:

Vážený pane doktore, v prŕloze posílám Vám rukopis Žebrácké opery a lituji, že nedošlo k provedení, ač mám návrhy, které jsem s Vámi propracoval, téměř hotovy. V uznání za tuto práci, která nebyla vůbec honorována prosil bych Vás, abyste byl tak laskav a při přidělování výtvarných spoluprací na mně častěji pamatoval. Děkuji Vám a zvu Vás i milostivou paní i Vaše přátele velmi vřele $\mathrm{k}$ návštěvě výstavy moderních malířů v mých místnostech. $\mathrm{V}$ dokonalé úctě se Vám poroučím AH. (Soukromá sbírka)

Pokud jde o zmiňované výstavní prostory „v mých místnostech“, šlo nejspíše o výstavní prostory na adrese ve Štěpánské ulici číslo 16, kde měl Heythum vzorkovou prodejnu svého nábytku. ${ }^{36}$ Doklad k existenci výstav představuje několik zachovaných listů s podpisy návštěvníků. První z nich je datován 1. března 1931, kde se nalézá 46 podpisů, mezi nimiž jsou výrazné osobnosti tehdejší kultury, z nichž jmenujme např. „Dr. Vančura, Stanislav Neumann, K. Dostal, Wachsman, Honzík, Jar Ježek, Ing Dr Chochol, Ant. Kybal, Vítězslav Nezval [...]“37 a další (Soukromá sbírka). Rovněž dne 15. května 1931, kdy se konala tamtéž vernisáž kreseb a plastik Makovského a Wichterlové, můžeme mezi návštěvníky číst jména jako „St Neumann, Ot. Novotný, Toyen, Karel Dvořák, Z. Rykr, Míra Holzbachová, Fragner, Ant Havlíček, Dr Konrád, Dr Wichterlová, Zelenka“ a dalšíi. ${ }^{38}$

Vraṫme se však zpět do roku 1928, kdy se skutečně obnovila Heythumova spolupráce s Národním divadlem, konkrétně opět s režisérem Karlem Dostalem. Stalo se tak při přípravě O’Neillovy hry Velký bưh Brown, která měla premiéru 11. února 1928. K této inscenaci se zachovaly tři dosud neznámé dopisy K. Dostala, které hovoří nejen o vztahu tvůrců, scénických vizích, ale i o problémech kolem výše honoráře. V prvním z nich Dostal píše:

36 Méně pravděpodobně na adrese Nad štolou Rudolfovou 20 (na pražské Letné).

37 Cituji přesně tak, jak jsou osobnosti podepsány.

38 Další návštěvnické podpisy jsou datovány 24. května, 27. května a 3. června 1931. Jiný doklad k provozu galerie dosud nebyl nalezen. 
Drahý příteli, včera jsem Vám dal poslat knihu Browna, dnes jsem obdržel Váš dopis. Děkuji. Jsem, věřte, tak rád, že se mi zase naskýtá přiležitost s Vámi pracovat. Krátce před vánocemi jsem se dozvěděl od Dr. Štorch-Mariena, ${ }^{39}$ že jste opět zdráv a v plné činnosti. První moje režie od té doby - a první po delší době vůbec - [...] ihned na cestě k Vám. Ta žádost o Vaši spolupráci - v tom je jistě také trochu prominentního sobectví. Především však radost z uzdravení hodnotného člověka, ke kterému jsem vždy cítil živé osobní sympatie - a proto právě spěchám, abych dal výraz potěšení z jeho „reaktivizace“ v našem divadelním životě. Bylo by neodpustitelným hříchem, aby z ní těžili jen v Olomouci a Praha aby vyšla na prázdno. To je moje poctivé přesvědčení a těší mne proto obzvlášt, že Vás mohu uvítat právě při prríležitosti inscenace Browna, kterého pokládám za největší dramatické dílo posledního desetiletí a samozřejmě i za nejzávažnější repertoirní záležitost dosavadního vývoje letošní sezóny. Vy ani netušíte, kolik radostného ohlasu ta zpráva z Olomouce, tlumočená Štorch-Marienem vyvolala u všech lidí dobré vůle, kteří byli často myšlenkami u Vás v sanatoriu. [...] výprava „Browna“ bude ještě komplikována požadavkem sochaře [...] Ale o tom dosud nemluvím, dříve se i o tomto bodu musíme dohodnouti mezi sebou. Doufám, že Vás dílo bude zajímat a těším se na Vás. Pište, kdy přijedete, zařídím se. Tisknu Vám ruku s přáním zdraví a všeho zdaru v novém roce, Váš Dostal. (Soukromá sbírka, Dopis režiséra Dostala z 29. 12. 1927) ${ }^{40}$

Už za šest dní však píše Dostal další dopis, v němž původní nadšení poněkud koriguje, nebot’ si je evidentně vědom, že by Heythum mohl chtít s vidinou práce v Praze ukončit své angažmá v Olomouci. Zároveň popisuje svou představu o scénografii, což je pro nás velmi cenné, protože Heythumův návrh neznáme:

Milý Př́íteli, nemám ještě od Vás odpověd', mám však za to, že se o věc zajímáte. Protože však náhle povstaly v ředitelství ND pochyby [?], neměl-li by být připravovaný repertoár trochu přeházen [?], spěchám, abych Vás prozatím zdržel v Olomouci. ${ }^{41}$ [...] Vyčkejte tedy, prosím, několik dní s jakoukoliv prací. Zpravím Vás ihned, jakmile budu mít jistotu o pořadu mých režií... Zhruba naznačeno: pro toho Browna si představuji cosi jako „neokované scenerie, jež by teprve poslední scénou nabyly suché, tvrdé reálnosti [?] až strašidelné. Jinak scéna jen cosi předstírá, stejně jako B. nebo Dionovy masky. Je taková, jak by se ráda jevila navenek. Brownův dům koketuje se svou amerikánsky uniformní neosobností, Dionův byt s bídou a výsměšnou nahotou jeho vnitřní nezakořeněnosti - bezzemek nemá vlasti, nemá domova.

Musí být, myslím pracováno v kontrastech (B-D): tedy v černé a bílé, zlato-holé dřevo a p. nějaké barvičky [...] umělé květiny. Zdání náhruživé atmosféry. (Náhražky za lásku, zapomnění, skutečnosti). Zatím tedy trpělivost. S upřímným pozdravem a stisknutím ruky Váš KD (Soukromá sbírka, Dopis Dostala Heythumovi z 3. 1. 1928)

39 Otakar Štoch-Marien (1897-1974) nakladatel, spisovatel, básník, publicista, který provozoval nakladatelství Aventinum (1919-1931 a 1945-1949). V rámci nakladatelství fungovala v letech 1927-1930 rovněž galerie výtvarného umění nazvaná Aventinská mansarda.

40 Zmíněn nabízený honorář „2000 Kč za výpravu včetně figurin i jedné po př. dvou cest do Prahy [...] citelně překračuje nynější zvyklosti ústavu“.

41 V této době je ještě Heythum šéf výpravy v Olomouci a bude jím ještě do sezóny 1929/30, v Olomouci své působení ukončí inscenacemi Farma pod jilmy a Žebrácká opera na začátku roku 1930. 
V následujícím nedatovaném dopise reaguje Dostal na scénický návrh, který obdržel od Heythuma, a z jeho poznámek již můžeme usuzovat o konkrétní podobě zamýšlené scénografie:

Milý příteli, zaslaný návrh je velmi hezký, klidný, formálně ryzí. (Škoda, že toho žlutého světla na koberci nedocílíme.) Nepřekáželo by Vám, kdyby nahoře nad domem byla fa. Browna Antony, střídavě světélkující a zhasínající? Nejlíp taková, která se objevuje po písmenech a dokončena mizí, aby se v příštím okamžiku opět počala vyvíjet? Na půdorysu chci zkusit malou změnu, kterou jsem na Vašem plánku vytečkoval. Dostaneme se tak alespoň s pohovkou (tou pod podiem) poněkud více do středu. Alespoň v tom směru mi, prosím, hled’te vyhovět, nehodí-li se Vám rozšíření do leva, rovněž vytečkované, jímž bychom nabyli trochu místa. Na tom však netrvám, ač se poněkud obávám pro herce jisté stísněnosti, zvážím-li, že bude na pódiu ještě stát nábytek. Vaše změna celkové silhouety je velmi správná. Jen se, prosím, informujte, lze-li se odvážiti takových rámů až do výše, Vámi proponované, bez jakékoli příčky. V šiřce $1 \mathrm{~m}$ je to jistě vyloučeno. Co soudíte o tom, abych si dal navrhnouti onen portrét Brownův Muzikou? Či bude líp nějaká Nechlebovština? Ten Muzika by byl prospěšnější ze stránky výtvarné - staromistrovský obraz by byl realističtější. Rád bych, aby ten obraz tvořil dvéře do Brownovy ložnice. Za něj také skryje Brown mrtvolu Dionovu (-aneb: Mrtvola za obrazem). Ale na kterou stranu s ním? Na tom rozšíření půdorysu směrem doleva by bylo myslím výhodné také to, že by se scéna sešoupla celá do negeometričnosti[?] - kvůli té rýsovně, jež má v posledním akti se scénou samou viditelně sousedit.

Konečně chci ještě připomenout, že považuji za důležité, aby všechny rámy byly přivrtány na podlaze - nikoli na praktikáblech. Počítáte s tím při výměře? Těším se na návrhy, pospěšte si. Zatím Vás srdečně zdraví Váš KD (Soukromá sbírka, Nedatovaný dopis Dostala Heythumovi)

Jak víme, byl to právě František Muzika, kdo nakonec namaloval obraz, o kterém je v dopise řeč. ${ }^{42}$ Pro dějiny scénografie je tato okolnost vskutku důležitá, protože právě tímto rozhodnutím (snad Heythumovým, snad Dostalovým?) došlo k tomu, že Muzika začal vůbec spolupracovat s divadlem. Byla to jeho zcela první scénická realizace, kterou započala řada sto sedmi inscenací, z nichž např. Androkles a lev (1931), Donogoo Tonka (1931), Hry o Marii (1936), Divadlo za bránou (1936) nebo Julietta Bohuslava Martinů (1938) a též Shakespearovy hry Bouře (1941) či Hamlet (1936) přinesly do moderního scénického obrazu zcela originální poetiku ovlivněnou magickým realismem a imaginativní malbou. ${ }^{43}$

Zachovaná kopie návrhu a půdorysu pro scénu „U moře“ pro inscenaci Velký bůh Brown (Soukromá sbírka) dokládá, že právě zde Heythum pracoval s rozměrným nápisem „High School“ na transparentním podkladu ${ }^{44}$ a vysokou prořezanou kulisou moderní architektury s okny, která byla prosvěcována „kontralichtem“, aby zároveň vrhala na jevištní podlahu mohutný stín. Poměrně úzká ústřední hrací plocha byla vymezena nepravidelně vykrojeným, mírně vyvýšeným pódiem evokujícím př́istavní molo. Podle

42 Návrh zachovaný v (DONM D 17799).

43 Ke scénickému dílu F. Muziky nejnověji (TETIVA a KOUBSKÁ 2012).

44 Snad tento nápis byl nahrazen světélkující reklamou firmy Browna. 
režisérova popisu šlo zřejmě o stejné pódium, které bylo využito i v ostatních interiérových scénách. Vzhledem k tomu, že se zachovalo jen pár fotografií z této inscenace, můžeme byt velmi rádi za Dostalem detailně popsanou scénickou vizi, i když je možné, že pro realizaci byla mírně změněna.

Další spoluprací Heythuma s Národním divadlem a Karlem Dostalem byl příběh o ženě vražednici, kterou osvobodila porota, ale odsoudila společnost, nazvaný Irena (Jaroslav Hilbert, 2. 11. 1929). Hlavní roli Ireny hrála populární Andula Sedláčková a inscenace o devíti dějstvích trvala téměř pět hodin. Čistý scénický objekt zobrazující exteriér funkcionalistické vily se zahradou odkazoval na nejmodernější architekturu. Karel Engelmüller napsal nesouhlasně: „,...] Výtvarník p. Heythum strašil v prvém a třetím dějství zas černou tmou za vilou, tam, kde se mluvilo o slunci, modru a kráse čarovného dne [...]“ (AND, Neurčený výstřižek) a jiná kritika chválila architekturu vily, ale „[...] méně se nám zamlouvala advokátní kancelář, vyřešená více programově než vynalézavě [...]“ (AND, Neurčený výstřižek, Autor kd).

Konečně došlo také na úspěšné ukončení spolupráce Heythuma s K. H. Hilarem. Již 23. prosince 1929 požádal Karel Hugo Hilar Heythuma o spolupráci na inscenaci Podivná mezihra (Eugene O'Neill, 3. 3. 1930). ${ }^{45}$ Za tuto experimentální hru, odehrávající se po první světové válce, získal Eugene O’Neill Pulitzerovu cenu. Jedinečnost textu spočívala především $\mathrm{v}$ tom, že hlavní postavy hovořily $\mathrm{k}$ divákům o svých vlastních myšlenkách formou vnitřních monologů. ${ }^{46}$

Scénografie pro hru Podivná mezihra navazovala na prověřenou podobu důmyslně rozčleněných interiérů s variabilními možnostmi zatažení a odkrytí jednotlivých prostor. Paluba lodi nebo zahradní restaurace dvou posledních obrazů svým funkcionalistickým tvaroslovím evokovaly nejmodernější lokality. Přesnost a střídmost prostoru ústředního interiéru domu byla ozvláštněna výrazným schodištěm. Zcela v protikladu k přesné a kultivované tvarovosti interiéru navrhl Heythum zábradlí, divan, křesla a lehátko, využívající volutový tvar. Ten zcela změnil charakter nábytku k dekorativnímu, téměř secesnímu dojmu. Je to s podivem, sám Heythum proti dekorativnosti výrazně vystupoval a prosazoval hlavně funkčnost. ${ }^{47}$ Šlo zřejmě o Hilarovu prosbu, snad o snahu ironicky degradovat prostor. Také kresba barevnými kř́dami, kterými navrhoval především některé rekvizity a nábytek, je v tomto období již u Heythuma nezvyklá. V inscenaci Podiuná mezihra hrála hlavní roli Niny Leedsové, která se potýká s problémem otcovství vlastního dítěte, opět Andula Sedláčková. A právě pro ni bylo určeno lehátko oblých tvarů s kolečkem a dvěma rukojetmi nazvané „trakářek-lehátko“, jehož návrh se nalézá ve sbírce architektury Národní galerie v Praze (NG, Sbírka architektury AP 602). ${ }^{48}$

45 Na plakátě uveden jako autor scény K. H. Hilar a A. Heythum.

46 Zcela aktuální inscenace měla na Broadway premiéru 30. ledna 1928 a již za dva roky ji realizoval Karel Hugo Hilar v Národním divadle.

47 Oproti návrhu byla realizace značně zjednodušena.

48 Dedikace návrhu: „trakářek-lehátko“ pro Andulu Sedláčkovou. Je rovněž možno, že tento kus nábytku byl využit pro civilní zakázku. Obdobný typ lehátka se nacházel v interiéru vily Na viničných horách na pražské Hanspaulce, kde Heythumovi po roce 1934 krátce bydleli (Soukromá sbírka, Fotografie). 
Skica, půdorysy a rozkresy jednotlivých oken a výplní stěn ke čtvrtému jednání inscenace Tř́dič štěrku (J. Hilbert, 18. 9. 1930, režie Karel Dostal) dokumentují znovu zajímavou práci s paravánovým systémem stěn (NM D 24052). Postaveny diagonálně a proříznuty vysokými klasicistními obloukovými okny dávají mnoho možností, jak nahlížet z ústřední místnosti vpředu jeviště do „vedlejších“ zadních prostorů tanečního sálu a kulečníkové herny. ${ }^{49}$ Scéna letiště se nezachovala, ale z kritiky můžeme soudit, jaké bylo její působení na diváky: „Ant. Heythum [herce] zasadil do průsvitných lehounkých mřížových konstrukcí, z nichž zvláště letiště se svou prostotou nekonečna znělo oním jakoby sivým tónem, jejž ze hry cítíme“ (KONRÁD 1930: 4).

Scénický prostor pro Hilbertovu Pěst (26. 11. 1930, režie K. H. Hilar) vymezovaly tři nápaditě zalomené paravánové stěny (NM D 24036). Jejich rozměrná pole rozdělovala přední a zadní část jevištního prostoru tak, že každé pole se mohlo zatahovat a rozkrývat samostatně a každé bylo pojednáno rozdílným textilním materiálem. Kombinací odkrývaných segmentů bylo možno vytvořit varianty prostoru, který byl jinak stylově určován mohutnými rondokubistickými zárubněmi oken a dveří. Zachovaná tužková půdorysná skica datovaná 19. listopadu 1930 naznačuje dříve zamýšlený horizont ve tvaru písmene U, který měl být zřejmě vykryt černým sametem. Zachycuje také původní režisérovu představu o umístění jednotlivých kusů nábytku. ${ }^{50}$

Další soudobou hru ve scénografii A. Heythuma, napsanou anglickým autorem Benn W. Levym ${ }^{51}$ v roce 1928, komedii o třech obrazech Láska a uměni (22. 10. 1930), režíroval opět Karel Dostal. Hra pojednávala o nezávislé ženě, která opustí manžela a dvě malé děti, aby žila s umělcem. Děj se odehrává ve chvíli, kdy se hlavní hrdinka po dvaceti letech setkává se svou rodinou. ${ }^{52}$ Scénografie byla postavena na kontrastních prostorech malířského ateliéru a interiéru středostavovské rodiny s historizujícím nábytkem a květinovými potahy. V ateliéru využil scénograf citace obrazů Matisse a Picassa, aby vyjádřil umělcovu svobodomyslnost. Karel Engelmüller označil výpravu za „působivou, vkusnou a odvážnou“ (AMP, Neurčený výstřižek, AND).

$\mathrm{K}$ vůbec nejznámějším a nejslavnějším inscenacím Antonína Heythuma na scéně Národního divadla patří Shakespearův Kupec benátský (16. 1. 1931, režie Karel Dostal), inscenaci scénograf vypravil ve dvou kontrastních rovinách. S konstrukčním řě̌ením architektury dóžecího paláce výrazně kontrastovala textilně řešená scéna Shylockova domu a židovského ghetta, kdy v pravé části jeviště na garnýži ve tvaru písmene „S“ zavěsil rozměrné plátno s malbou evokující zatuchlé, navlhlé a plísní pokryté zdivo domů benátské židovské čtvrti. Toutéž malbou pak pojednal zleva jeviště umístěnou paravánovou stěnu. Mezi oběma rozdílně působícími malbami vznikl hluboký průhled na prospekt zachycující benátský záliv s bazilikou St Giorgio Maggiore a benátskou zvonicí. V obrazech dóžecího paláce nebo soudní síně se objevila graficky čistá konstrukce

49 Honorář obdržený za scénu ke hře Třidič štěrku činil 2000 Kč.

50 Kresba půdorysu a doklad o zaplaceném honoráři 500 Kč (Soukromá sbírka).

51 Benn W. Levy (1900-1973) byl dramatik a poslanec labouristické strany v poslanecké sněmovně parlamentu Spojeného království Velké Británie.

52 Hra byla úspěšně inscenována na Broadwayi od listopadu do prosince roku 1930, roli Judy Bottle hrála Katharine Hepburn, inscenace zde byla hrána 50×. Původní název hry byl Art and Mrs. Bottle. 


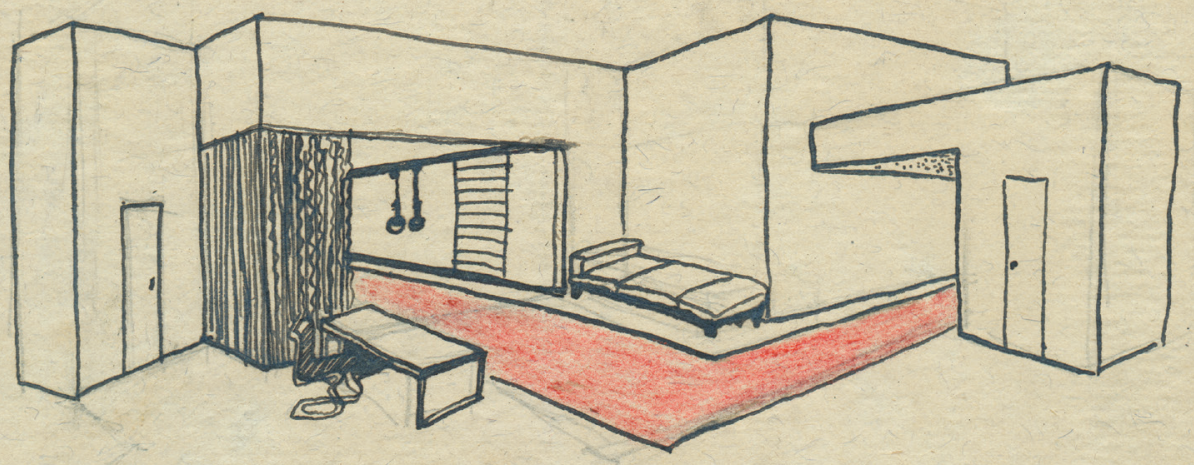

Hilbent fa'kon Sindèn'I.joduámí.
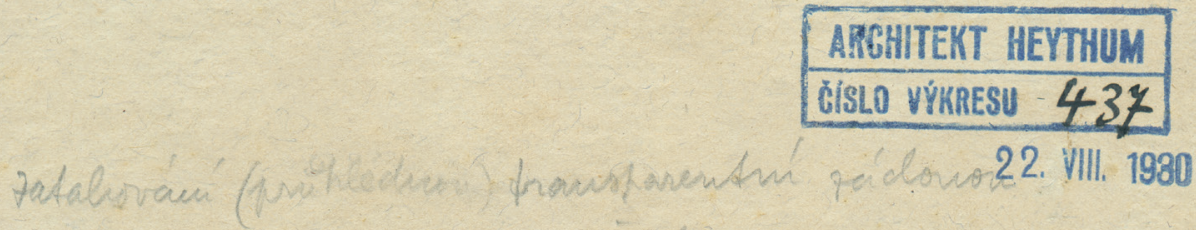
jebinh a deruh na oricem na tenase

Obr. 10: Návrh scény Vila sportsmana. Třidič štěrku. 1930. Soukromá sbírka. 


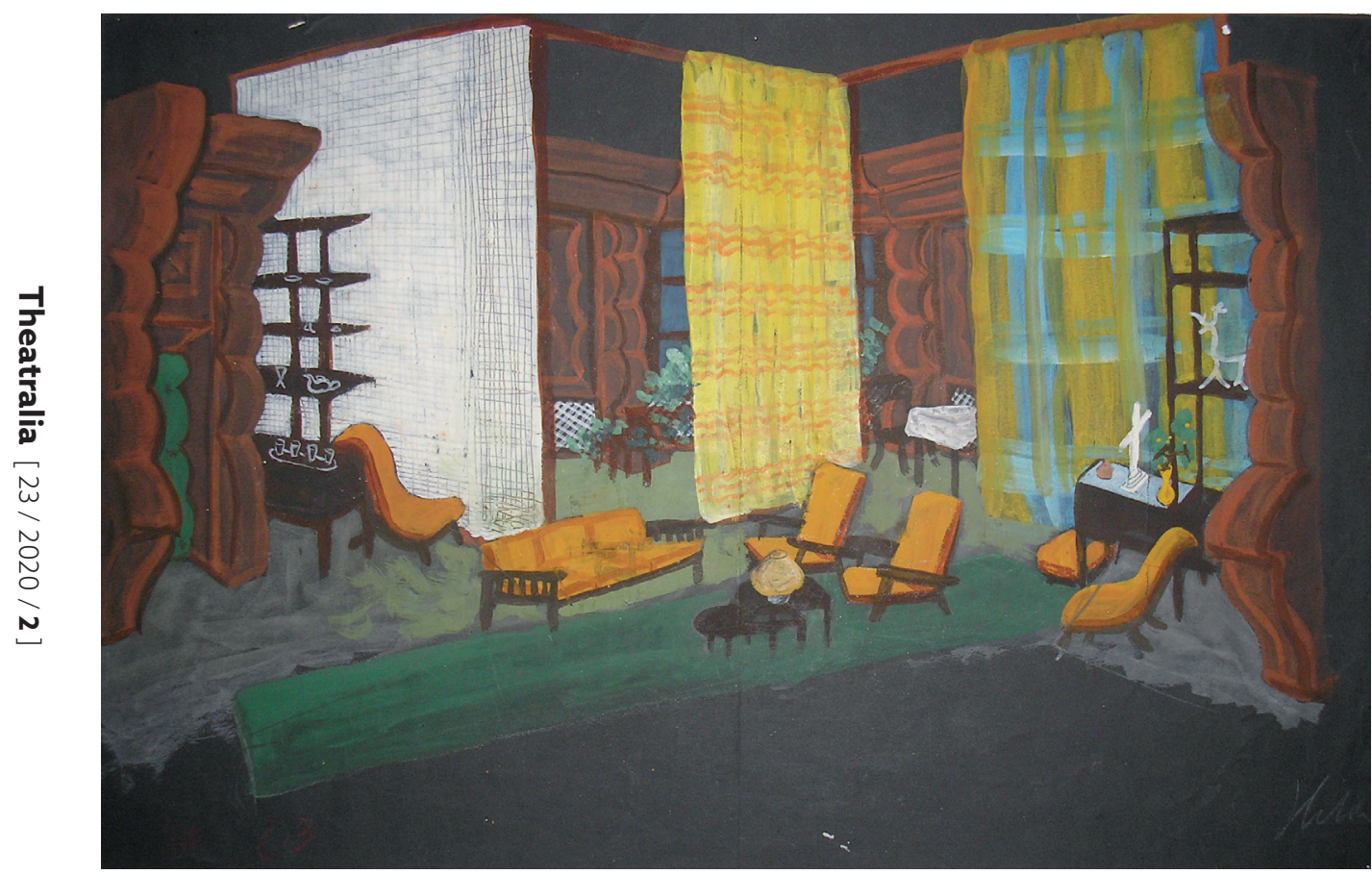

Obr. 11: Návrh scény. Pěst. 1930. NDM S-VIla-6e_D 24.036.

zobrazující gotickou architekturu. Ironický nádech pak scénograf přisoudil čistě formovaným kostýmům bez ornamentů, které využívaly „fašistické čapky“, ${ }^{53}$ voskové plátno a barevné samety, kostýmy tak vždy korespondovaly s barevností využitou na scéně. ${ }^{54}$

Jaké bylo finanční ohodnocení Heythumovy práce na této inscenaci, se dozvídáme díky korespondenci mezi ním a K. H. Hilarem. 19. prosince 1930 poděkoval Heythum dopisem za „svěření výpravy ke Kupci benátskému“ a požádal o obvyklou sazbu za dekoraci ve výši 500 Kč. Vzhledem k tomu, že scénograf navrhl sedm dekorací, přesně popisuje pořadí scénických obrazů a vyčísluje celkový požadovaný honorář na 3500 Kč.

9. ledna 1931 na toto vyúčtování reagoval K. H. Hilar následovně:

[...] k Vašemu dopisu ze dne 19. prosince sděluji Vám, že nemohu Vám navrhnouti za výpravu hry Kupec benátský více, než měli dosud přední výtvarníci Národního divadla, ve hrách Shakespearových již vyzkoušení, zatím co běží zde o Vaši první shakespearovskou inscenaci. Dosavadní maximální honorář obnáší 3000 Kč. Žádám současně ředitelství, aby Vám tuto částku za výpravu poukázalo. S veškerou úctou Hilar. (Soukromá sbírka, Dopis šéfa činohry ND Hilara ze dne 9. 1. 1931) $)^{55}$

53 Poznámka scénografa u kostýmních návrhů (NM D 21787, NM D 21789, NM D 21795).

54 Vpisky Heythuma na kostýmních návrzích, viz pozn. 79.

55 Př́ípis z 11. ledna 1931 pro účtárnu dokládá, že Národní divadlo Heythumovi skutečně vyplatilo avizovaných 3000 Kč, a doklad z 21. ledna 1931 dokumentuje vrácení dvou textů do knihovny Národního divadla: Kupec benátský a Ohnivý buben s hudební partiturou. 


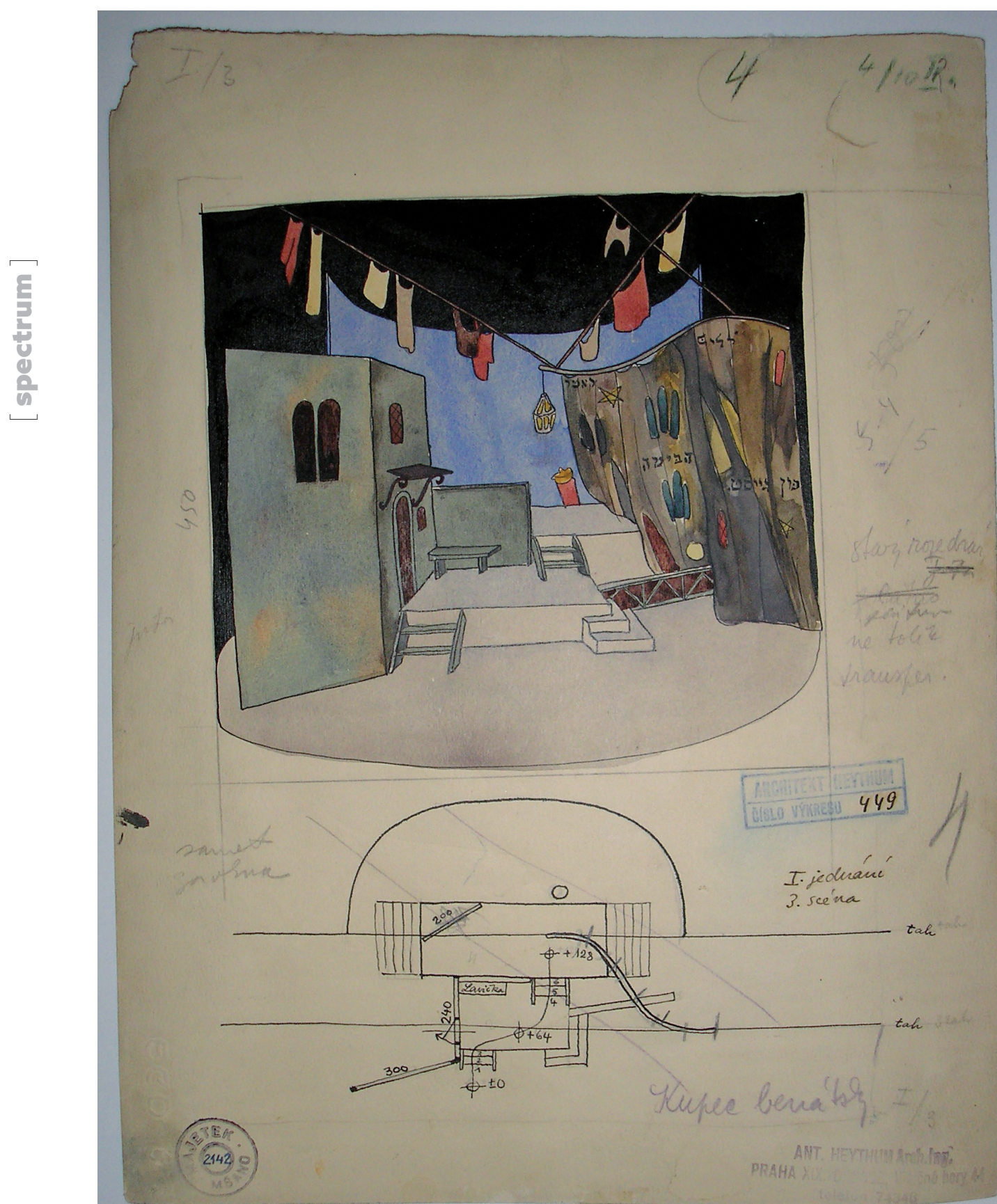

Obr. 12: Návrh scény. Kupec benátský. 1931. NDM S-VIlla-6c_D 25.903. 


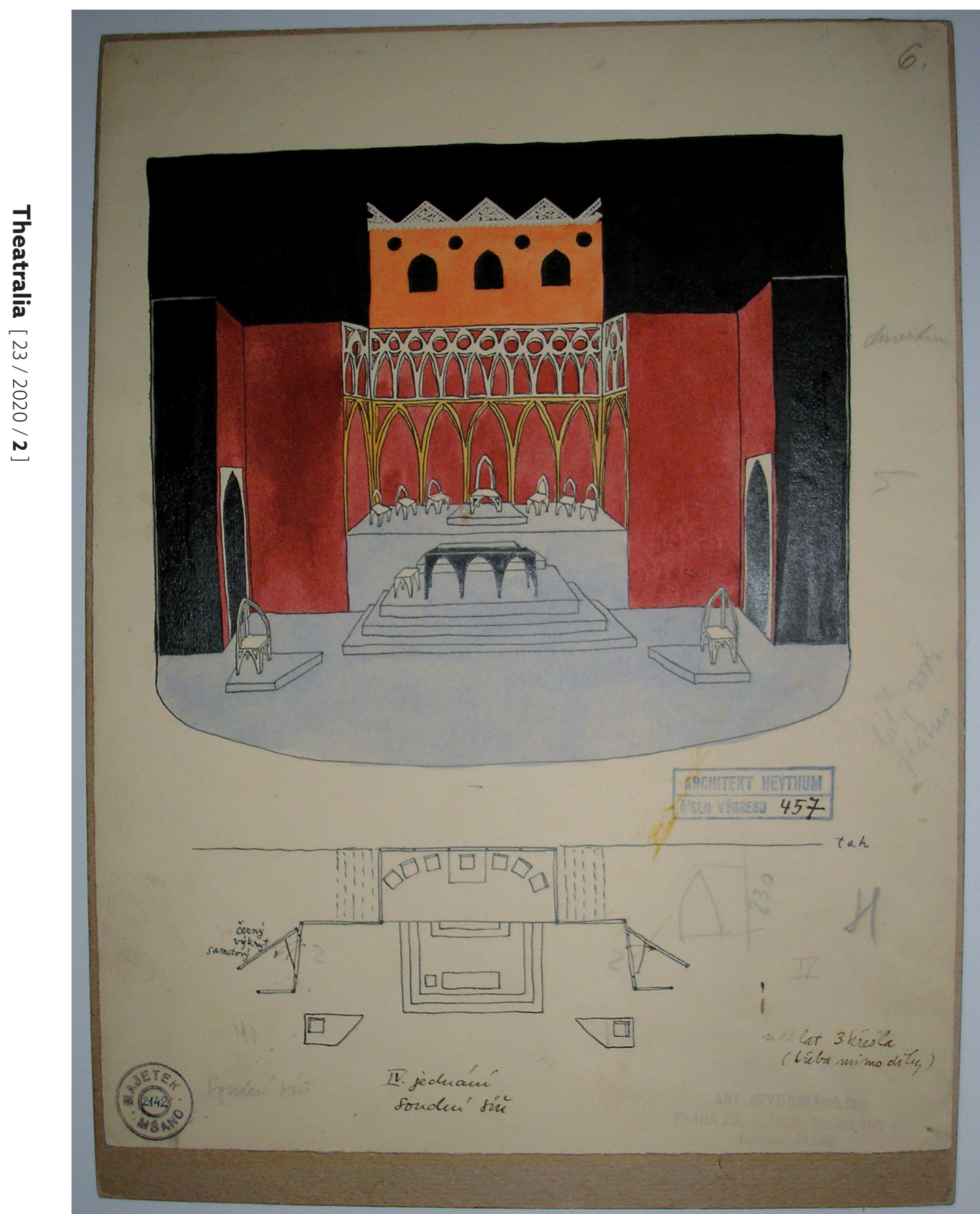

Obr. 13: Návrh scény. Kupec benátský. 1931. NDM S-VIIa-6c_D 25.905. 
Nespokojený scénograf zřejmě dlouho, tedy téměř tři měsíce váhal, zda má reagovat, aby vyjádřil nejen svůj nesouhlas s honorářem za Kupce benátského, ale celkově s platební situací scénografư, kteří pracovali pro naši první scénu. Nakonec se 1. dubna 1931 rozhodl a napsal vedení Národního divadla, že tak nízký honorář přijímá jen proto, „že je ve špatných finančních poměrech“, a navrhuje v dlouhém dopise minimální honorářový sazebník za návrhy na jevištní výpravu a kostýmy a snaží se jasně formulovat charakter scénografovy práce, z čehož by mělo vyplynout vyšší odměňování. Cituji zde podstatnou část, v níž nejprve charakterizuje pracovní nasazení scénografa, které je platné do dneška:

[...] Dle druhu práce rozeznáváme tyto výkony:

1. Přečtení divadelního kusu.

2. Předběžné porady s režisérem.

3. Zhotovení návrhů a konečných výkresů pro dílny.

4. Dozor v divadelních dílnách při zhotovování výpravy.

5. Účast na hlavní zkoušce.

6. Dozor na generální zkoušce.

Minimální honorář za výkresy i když sestává pouze z 1.dekorace obnáší...1000.00 Kč protože všechny výkony uvedené ve svrchu uvedených položkách zůstávají stejné, at̉ má kus 1 . nebo 5. jednání.

Za druhou a každou další dekoraci.... 500.00 Kč

Takže za normální divadelní výpravu o 3. různých dekorací honorářová odměna obnáší 2000.00 Kč. [...]

[...] Výtvarník je povinen svědomitě dle svých odborných nejlepších vědomostí vykonati vše, co jest u něho objednáno. Př́ípadné odchylky od původních výkresů mohou býti v dílnách provedeny jen s výslovným svolením navrhovatele. Výtvarníkovi zůstávají podle zákona ze dne 24. XI.1926, Sb.z. a n.č. 218) vyhrazena veškerá práva autorská, zvláště zůstávají jeho vlastnictvím návrhy provedených i projektovaných divadelních výprav, a přísluší mu výhradní reprodukční právo jak výkresů tak hotových výprav. (Soukromá sbírka, Dopis A. Heythuma vedení ND ze dne 1. 4. 1931)

Na závěrečnou klauzuli z dopisu o výhradním reprodukčním právu se Heythum brzy odvolal během příprav inscenace Jaro národi̊ ${ }^{56}$ (Adolf Nowaczyński, 19. 6. 1931, režie Karel Dostal) dopisem, jímž požádal vedení Národního divadla o možnost zapůjčit si vlastní návrhy a podle nich si vypracovat kopie. Šlo mu nesporně hlavně o to, aby mohl tytéž návrhy využít rovněž v jiných divadlech. Obratem obdržel dopis od K. H. Hilara: „[...] Dovoluji, aby si po generálních zkouškách vyzvedl své originální návrhy na jevištní výpravy pod podmínkou, že do 4.dnů opatří pro archiv ND věrné kopie.

56 Točna, na níž byly postaveny různě vysoké scénické objekty evokující moderní architekturu, schodiště nebo okrouhlé koleje, navazovala evidentně na scénografovu zkušenost z prostorově promyšlené koncepce inscenace o zlodějičkovi Todo je outsider (Vilém Werner, 31. 8. 1929) režírované Viktorem Šulcem. 
Povolení toto platí už pro výkresy ,Jaro národů““ (Soukromá sbírka, Dopis od K. H. Hilara 3. 7. 1931). ${ }^{57}$

Další zachované dopisy dokládají, že se Heythum pokoušel uplatnit již provozovanou pražskou scénografii v jiných divadlech. ${ }^{58}$ Ve stejné době se neúspěšně snažil působit jako pedagog na proslulé Škole uměleckých remesiel v Bratislavě a zároveň hledal pomoc při hledání svého uplatnění i u přátel. Tomu nasvědčuje např. dopis Vladislavu Vančurovi, kterého žádá o přímluvu u ředitelství AB (Ateliéry Barrandov) a zmiňuje se o nedostatku pracovních příležitostí: „,...] nemám dohromady žádnou práci, než trochu těch návrhů pro divadlo a velmi zřídka nábytek [...]“ (Soukromá sbírka, Dopis Vl. Vančurovi na Zbraslav 15. 1. 1933).

Je tedy evidentní, že Heythumova finanční situace nebyla dobrá a umělec se snažil nalézt další zakázky, aby ji vylepšil. Vzájemné vztahy mezi vedením Národního divadla a Heythumem výrazně ochladly, a dokonce se zdá, že začaly mít vliv na uměleckou úroveň a kvalitu jeho práce. Je to zřejmé například z Hilarova dopisu týkajícího se inscenace Děti naši doby (Robert Adolf Stemmle, 20. 4. 1933, režie Karel Dostal): „[...] žádám, abyste po dohodě s režií zjednodušil diagramové prospekty do hry ,Děti naší doby“, poněvadž jejich provedení by si žádalo celého týdne podrobného kreslení. Naproti tomu dodal jste návrhy na tuto hru teprve včera o 1 hod. odpol. Nově upravené návrhy jest Vám dodati do zítřejšího poledne [...]“ (Soukromá sbírka, Dopis ze 7. 4. 1933). Školská veselohra o pěti obrazech měla premiéru ve Stavovském divadle a byla jednou kritikou označena nikoli za „divadlo, ale spíše jakýsi debatní večer s pochybnou obhajobou moderní, volné pokusné školy“ (Soukromá sbírka). ${ }^{59}$ Podle návrhu měl prospekt s nápisem „Byty v předměstí a promítanou pavlačovou kompozicí se sušícím se prádlem dominovat jevištnímu obrazu. Ten zachycoval interiér bytu se třemi místnostmi: studentským pokojem, obytnou kuchyní a ložnicí rodičů. I tentokrát Heythum využil nárožně postavených kulis, které poutavě výtvarně i šikovně provozně vymezovaly jednotlivá dějiště a umožňovaly nahlížet do jednotlivých „interiérů“ současně. Bílá železná postel, sporák, rozkládací pohovka, manželské postele, skleník pro vystavení hrnečků, skla a sošek to vše byly detaily důvěrně známé všem současníkům. Obdobné řešení s promítaným screenem s čísly měla též scéna ředitelny a sborovny. Pro scénu radnice byla zvolena kuželková balustráda, na níž v zavěšených košících byly vymalovány květy pelargonií. Heythum vedle kresleného návrhu napsal: „[...] vše namalováno ale s konturou názorně učitelsky! Žádný expresionismus ani impresionismus, ale názorná školská kolorovaná kresba“ (Soukromá sbírka). Je tedy patrno, že celá scéna radnice se vymezovala ironicky vůči realismu a ilustrativismu, který zde evokoval zastaralé vyučovací metody. Slavnostní síni ve škole dominovaly nápisy „Muzeum kýčů nebo „Pryč s kýčem“. ${ }^{60}$

57 Ke stejnému problému se později vyjadřuje Ředitelství ND v Praze: „nemám námitek, abyste si vždy po generální zkoušce vyzvedl své návrhy výprav k zhotovení kopií za podmínky, že do 4 dnů je vrátíte na potvrzení archivu ND [...]“ (Soukromá sbírka, Dopis z 25. 1. 1932).

58 Bratislava, Ostrava.

59 Neznámý výstř̌ižek vylepen u návrhu, obrázek z výstavy 1935 v Uměleckoprůmyslovém muzeu, foto návrhu.

60 K této inscenaci s původním názvem Boj o školu je zachováno ve sbírce architektury Národní galerie devět scénických návrhů a světlotisků (NG AP 634-001 až 634-009). 
Existují rovněž doklady, že Heythum byl požádán Karlem Dostalem o spolupráci na Hauptmannově inscenaci Před západem slunce (Soukromá sbírka, Vzkaz Dostala Heythumovi). Inscenace měla premiéru 28. února 1933, avšak jako scénograf je na plakátech uveden Václav Gottlieb. Proč byla tato inscenace nakonec jeho dílem, není dosud jasné.

Ze všech inscenací, které zrealizovali Dostal s Heythumem v Národním divadle, vyvolala nejširší kritický ohlas inscenace Aladin (J. Klokoč, 9. 12. 1933), které bylo věnováno devětatřicet poměrně příznivých kritik. ${ }^{61}$ Devět obrazů v inscenaci o mladém finančníkovi, který se ocitne bez práce a pomocí fikce získá zpět své postavení, se odvíjelo ve zcela rozdílných dějištích (např. banka londýnské City, londýnská Picadilly, srbská kavárna Avala v Praze, žižkovské podkroví, lázně Biaritz na baskickém pobřeží, Lurdy a další). Tento úkol scénograf vyřešil především pomocí projekce, což se ukázalo jako provozně praktické: „Architekt Heythum mezi rámovými konstrukcemi, světelnými projekcemi, závěsy a světly vytvořil střídu obrazů nejen vděčně vtipných na jedné straně, nýbrž i slohově a jevištně velmi účinných, nejednou s prostorovou a tvarovou básnivostí" (Lidové listy 13. 12. 1933).

Z dnešního pohledu je paradoxní, že právě scény využívající konstruktivního principu tak vysoce dnes ceněného v souvislosti s Heythumovou scénografií byly několika kritiky hodnoceny negativně a charakterizovány jako „několik pitvorných latí (které) nahrazovalo interieury. Kolik se tu ztratilo nálady [...]“ (ENGELMÜLLER 1933) anebo byly označeny za „anachronismus“ (Pražské noviny 12. 12. 1933). ${ }^{62}$ A tak hlavně M. Rutte vyzdvihl scénografovu práci: „Výborným pomocníkem mu (režisérovi) byl Ant. Heythum, jenž vytvořil z konstruktivních náznaků, doplněných obrovskými projekcemi ulic a chrámů, řadu sugestivních scén vzácné výtvarné čistoty a i úspornosti..." (RUTTE 1933). ${ }^{63}$

6. března roku 1935 náhle zemřel šéf činohry Národního divadla a režisér K. H. Hilar. Národní divadlo připravilo posmrtnou výstavu památek na osobnost a uměleckou činnost bývalého šéfa činohry. Podle dopisu ze dne 4. dubna 1935 zapůjčil A. Heythum na tuto výstavu své scénické návrhy. Jejich přesný seznam neznáme, avšak je evidentní, že právě Heythumova scénografie, určená hlavně pro inscenace jiných režisérů, dokumentovala progresivní práci z významné etapy Hilarovy éry v Národním divadle.

Naopak víme zcela přesně, co bylo vystaveno na rozsáhlé výstavě dokumentující celé dosavadní scénické dílo čtyřiatřicetiletého Antonína Heythuma, která byla pořádána $\mathrm{v}$ prostorách Uměleckoprůmyslového muzea v září roku 1935. 4. záŕí 1935 si Heythum od ředitelství Národního divadla zapůjčil celkem 18 scénických návrhů a 20 kostýmů. Jednalo se podle soupisu o „dekorační návrhy her Kupec benátský, Druhý břeh, Todo je outsider, [...] Třidič štěrku, Nový Mesiáš, Slabé pohlavi, Let královny“ (Soukromá sbírka, Dopis ze dne 4.9. 1935). Tištěný katalog k výstavě uvádí přesný seznam

\footnotetext{
61 Kritiky si A. Heythum uchoval mezi nejdůležitějšími doklady (Soukromá sbírka).

62 Týkalo se např. scén: Žižkovská mansarda, vinárna a banka.

63 Honorářové ocenění Heythumovi práce dokládá dopis ze dne 2. listopadu 1933 z ředitelství ND Praha: „za návrh výpravy dekorační a kostýmní pro hru Jana Klokoče Aladin poukazuji Vám k výplatě... Kč 1.200“ (Soukromá sbírka). Honorář vyplacen 9. listopadu 1933 na základě dopisu ze dne 4. července 1933. Dále viz Dobropis na divadelní vstupenky ve výši 100 Kč (vše Soukromá sbírka).
} 


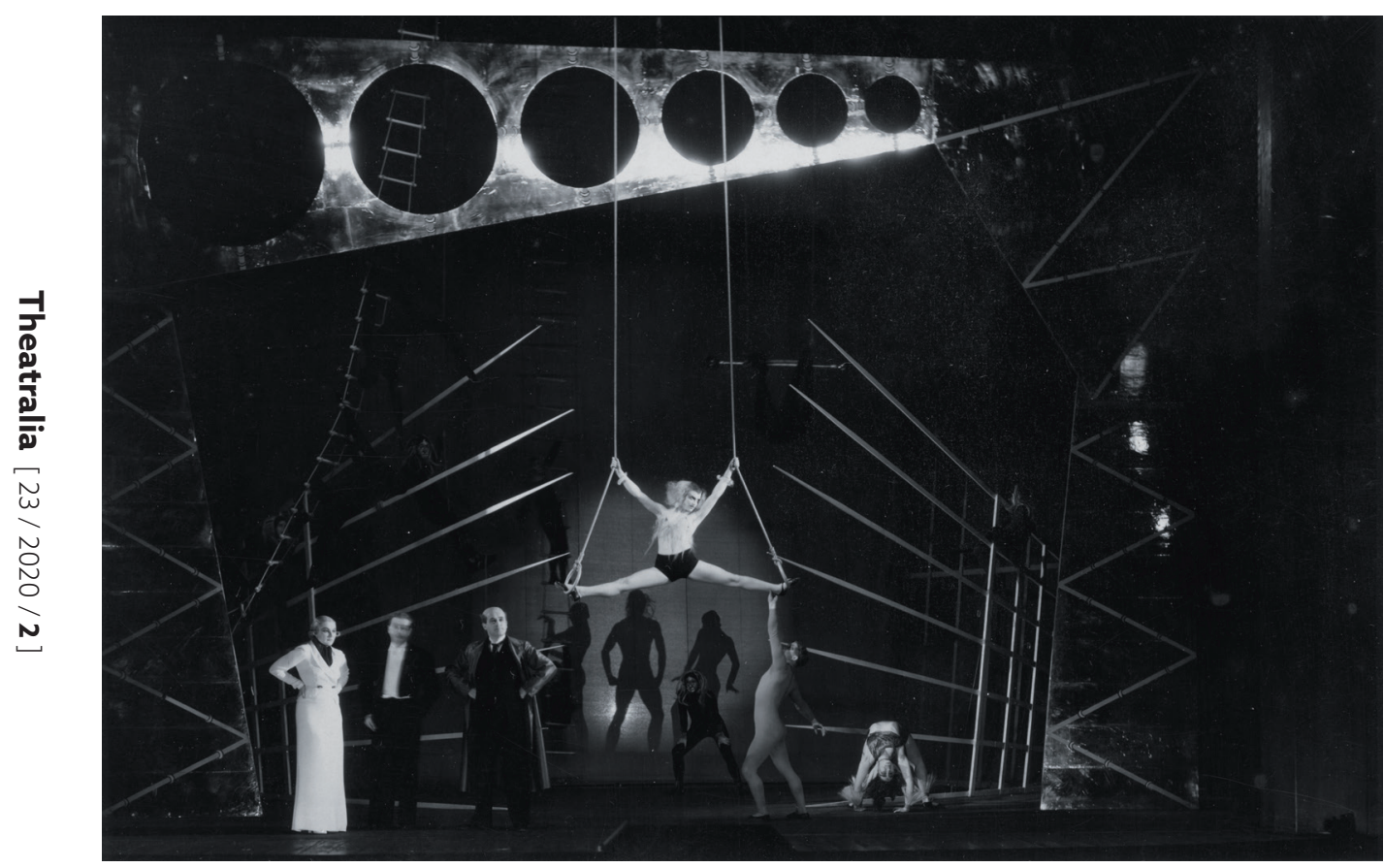

Obr. 14: Návrh scény. At’žije divadlo, 1935. Soukromá sbírka.

vystavených položek. Architektonickou podobu výstavy si navrhl sám Heythum: „Na sytě modrých stěnách visely ve žlutých paspartách, tvořících jednolitý pruh, scénické a kostýmní návrhy doplněné fotografiemi a půdorysy, v pěti pylonech byly zapuštěny osvětlené makety a kolmá stěna byla polepena divadelním plakáty a denními cedulemi“ (Soukromá sbírka). Výstava byla zahájena 18. září 1935 vicepresidentem Obchodní a živnostenské komory dr. Františkem Oberthorem a úvodního proslovu se ujal profesor Václav Tille.

Téhož roku uplatnil Heythum satirou a ironií prodchnutý pohled na historickou i moderní scénografii v inscenaci At’ žije divadlo (Henri-René Lenormand, 6. 12. 1935, režie Karel Dostal), kde se v podstatě velmi energicky a kultivovaně vysmíval úsilí jak inscenátorů iluzivního realistického divadla, tak i modernistům a jejich cirkusově abstraktním snahám vytvořit co nejuniversálnější scénický tvar. Osm dekorací zobrazovalo postupně různé scény i zákulisí pařížského omšelého bulvárního divadla a německého strohého moderního berlínského divadla. Použil zde například přední oblouk lesa se zadním prospektem, na němž byla namalována pustá zimní realistická krajina. V kontrastu pracoval s nejmodernějšími prostorotvornými metodami v čele s holou dřevěnou konstrukcí scénického objektu nebo žebříky a hrazdami i s řadou světelných efektů, vtipně využil hybných stínů ostře nasvětlených dramatických postav, a nakonec ukázal projekční přístroj jako jednu z nejnovějších živoucích nadějí moderního divadla. O dva roky později byly zmíněné návrhy publikovány v měsíčníku TheatreArts (HEYTHUM 1937: 903-904) a podrobný článek k této inscenaci napsal Jaroslav Švehla roku 
1971, v němž do detailu popsal jednotlivé proměny a zdokumentoval řadu originálních Heythumových nápadů (ŠVEHLA 1971: 54). ${ }^{64}$

Další inscenací v režii Karla Dostala, k níž Hethum vytvořil scénografii, byla fraška George Bernarda Shawa o vlivu peněz na lidské chování nazvaná Milionářka, která byla uvedena na začátku roku 1936 (17. 1. 1936). Zachovaný scénický návrh je dnes uložen v Metropolitan Museum of Art (US) v New Yorku (The Elisha Whittelsey Collection No 62570) ${ }^{65}$ Odhalená konstrukce bočních kulis i krovu vymezujících hrací prostor připomíná v lecčems slavnou Farmu pod jilmy, avšak na rozdíl od farmářského srubu evokuje spíse stavbu z hrázděného zdiva. Celý prostor byl vymezen v půdorysu diagonální kulisou, přičemž zadní stěna byla prolomena členitými okny. ${ }^{66}$

Počátek spolupráce na inscenaci Záríivá chvile (Keith Winter, 20. 3. 1936, režie Karel Dostal) dokládá dopis Heythuma režiséru Dostalovi, jenž byl napsán ve Vysokých Tatrách 15. února 1936:

Vážený pane režisére, [...] V časopisu Národní divadlo č. 9 na poslední stránce je psáno, že hra Zářivá chvíle přijde na pořad až 20 . března, nebude snad tedy vadit, když se z Tater vrátím koncem února do Prahy. Zatím mohl byste být tak laskav a nechal byste mně z činoherního archivu poslat knihu, abych po přečtení Vám event. poslal předběžné náčrtky. Je tady pěkně, sníh i slunce, škoda, že si nemůžete také v zimě dopřát dovolené. Poroučím se Vám v přátelské úctě a milostivé paní ruku líbám. Váš AH. (Soukromá sbírka, Dopis ze dne 15. 2. 1936 na Hrebienku v Tatrách)

Den předtím ovšem Heythum adresoval vedení divadla dopis, v němž požadoval, aby byl divadlem „dodržen tarif 1000,-Kč při hře s jedním nebo dvěma obrazy, za každou pak další dekoraci Kč 500,- [...]“" (Soukromá sbírka, Dopis ze dne 14. února 1936).

Reakce nedala na sebe dlouho čekat a od ředitelství Národního divadla obdržel Heythum následovný dopis:

[...] Obdržel jsem Váš dopis [...], ale zjištuji z něho s politováním, že požadavky, kterými podmiňujete svou výtvarnou spolupráci na této hře, jsou ředitelství ND zásadně a konkrétně nepřijatelné, a že bych Vám tedy za těchto podmínek výpravu řečené hry nemohl zadati [...] nemohu smlčeti, že honorář vypočtený podle zásad, které uvádíte, byl by zcela neúměrně vyšší než jaký kdykoli Národní divadlo platilo, a to i za poměrů ještě podstatně př́ínivějších, takže by za dnešních poměrů tím méně mohlo na takový honorář přistoupiti. Žádám Vás proto, abyste své požadavky revidoval, a oznámil mi pak s udáním počtu dekoračních obrazů, pokud se týče i kostýmních figurin, jaký nejnižší honorář jste ochoten přijmouti za tento návrh výpravy [...]. (Soukromá sbírka, Dopis ze dne 18. 2. 1936)

64 Za návrhy k osmi dekoracím bylo Heythumovi vyplaceno 800 Kč (Soukromá sbírka, Doklad ze dne 30. 10. 1935).

65 Do této sbírky se snad mohl návrh dostat po roce 1939, kdy Heythumovi žili v USA.

66 V dopise ze dne 31. prosince 1935 z ND je uvedena výše honoráře za inscenaci Milionářka 1200 Kč. 

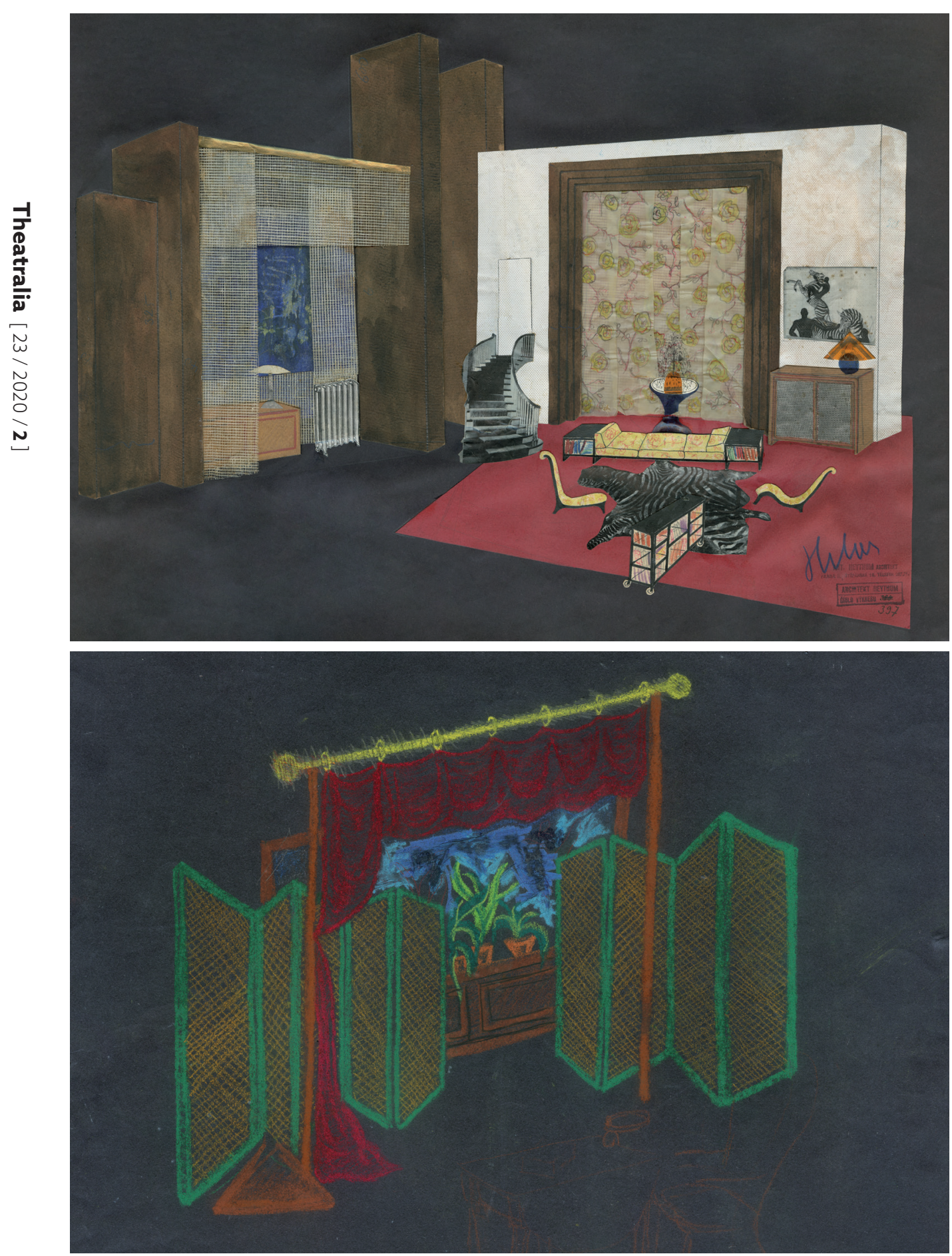

Obr. 15 + 16: Návrh scény. Zářivá chvíle. 1936. Soukromá sbírka. 
I přes toto opětovné řešení finančního ohodnocení scénografa Heythum na inscenaci nakonec pracoval (Soukromá sbírka, Dopis z ředitelství ND z 26. 2. 1936). Inscenace se odehrávala v interiéru domu, jehož odhalená členitá konstrukce zastřešovala variabilní prostory interiéru, v němž vznikla čtyři základní dějiště. Levé části scény dominoval cihlový krb a v prostředku scény stoupalo schodiště do patra. Scéna v konstrukčním principu rozvíjela kompozici z inscenace Milionářrka (Soukromá sbírka).

Snahu o vylepšení platu za svou práci však Heythum nevzdal. Dopis, který napsal ředitelství Národního divadla zhruba měsíc před poslední premiérou inscenace režírované Karlem Dostalem, má již poměrně ostrou dikci a dává tušit brzké ukončení více než dvanáctileté spolupráce:

[...] K Vašemu lask. dopisu ze dne 18.t.m. v záležitosti honoráře za výpravu hry „Zářivá chvíle“ dovoluji si Vám sděliti [...] proč v každém svém dopise tak tvrdohlavě uplatňuji úpravu minim. honoráře, které bez smlouvání akceptují jiná divadla s kterými pracuji, (dokonce i brněnské divadlo platí za jednu dekoraci Kč 500,-) je to spíše zásadně, nebot svou práci, čas ztracený poradami a zkouškami si cením tak jako tak daleko více,- je to boj spíše pro budoucí výtvarníky, aby si mohli dovolit tomuto zaměstnání cele věnovat, jako je všude jinde v cizině, a jako jsem si to sám před 12 lety upřímně přál.

Když před třemi léty byl v Praze výtvarný spolupracovník New Yorkského divadla GUILD pan Lee Simonson, nechtěl našim honorářům vůbec věřit, nebot' v Americe stačí, aby výtvarník při scénování 3 her mohl být celý rok živ ve vlastním domě a klidně se věnoval odbornému studiu svého povolání. - I v Německu, když jsem byl v Divadelním institutu v Kolíně nad Rýnem, s podivem jsem konstatoval, že i v provinciálním divadle je ceněna výtvarná spolupráce u hry nejméně 1000 RM. - Ostatně nemusíme chodit tak daleko, ani v Praze mně to nechce nikdo věřit, že výtvarná práce u našich divadel se tak nízko cení, a kdo nemá pochopení pro ideální práci, nemůže tomu věřit a diví se proč to vůbec děláme. Doufám, že máte jistě také osobní porozumění pro naše těžkosti a prominete mně proto tento delší dopis. S veškerou úctou AH (Soukromá sbírka, Dopis ze dne 22. 2. 1936)

Na poslední spolupráci s režisérem Dostalem, na inscenaci Záríivá chvíle, navázaly ještě dvě inscenace režírované Vojtou Novákem uvedené na začátku nové sezóny, a sice Tančici safír o Isadoře Duncanové (7. 9. 1936) a Továrnik Dodsworth (7. 12. 1936) a celé Heythumovo angažmá v Národním divadle ukončil balet Nikotina (20. 3. 1937). Tím definitivně skončila spolupráce tohoto scénografa s pražským Národním divadlem.

Scénografie, které v Národním divadle Heythum navrhl nebo realizoval jak pro K. H. Hilara, tak Karla Dostala, patřily k těm, které můžeme z dnešního hlediska hodnotit jako progresivní př́edevším pro využití nových moderních scénických metod. Přesto měly práce zrealizované pro Hilara specifický charakter. Návrhy pro obě inscenace Pěst a Podivná mezihra využívají pro Heythuma nezvykle barevné tóny, a dokonce návrhy 
pro podruhé jmenovanou jsou jediné nakreslené hutnými tóny barevných kř́íd. ${ }^{67}$ Také pojetí prostoru je mnohem sevřenější, temnější a soustředěnější a postrádá lehkost.

Naproti tomu z inscenací režírovaných Dostalem vyzařuje větší hravost, uvolněná variabilita rozevřeného prostoru, výraznější snaha pomocí světla měnit atmosféru. Zdá se, že právě spolupráce s Karlem Dostalem odrážela větší souznění obou umělců ve smyslu utváření čistých moderních znaků.

Ve všech zmíněných inscenacích se Heythum snažil vymezit vůči jakémukoliv druhu iluzionismu, malî̌ské dekoraci a samoúčelné dekorativnosti. Jeho výtvarný jazyk směřoval k abstrakci, částečně se inspiroval sovětským konstruktivismem, a to hlavně v souvislosti s využitím odhalených konstrukčních rámů. Jeho časté využití promítacích pláten má kořeny v Craigových screens.

Typická pro Heythumovu scénografii v Národním divadle je hlavně snaha o rychlou proměnu dějišt pomocí variabilních paravánových stěn, tvarová abstrakce, kultivovaná a velmi umírněná barevnost, ${ }^{68}$ důmyslná typografická práce $\mathrm{s}$ písmem, využití nejmodernějšího způsobu svícení (barevné reflektory, rozptýlené světlo). To vše používal ve snaze vytvořit působivý moderní scénický obraz, který podporoval režijní interpretaci hry.

Heythum umně architektonicky pracoval s členěním podlahové plochy, aby odděloval jednotlivá dějiště a zároveň umožňoval vidět jednotlivé segmenty scénické stavby jako celek. Jeho inscenace na první české scéně neměly sice uvolněnost a gradaci inscenací, které známe z jeho spolupráce s avantgardními mladými umělci v čele s Jiř́m Frejkou, avšak rozhodně náležejí $\mathrm{k}$ těm, v nichž se kloubila architektonická tektonika s rytmizací dramatu. Princip diagonálního kulisového rozevření, dokonalé využití možností paravánového členění, variabilní skrývání a zatahování jednotlivých dějišt dokládalo přesné, př́ímo kombinatorní myšlení scénografa a dovolovalo do důsledku využít striktně formulovaný scénický tvar. Využití scénických objektů, které měnily vzájemné konstelace s pomocí točny, souviselo s jasnou snahou reagovat na změnu dramatického času a děje tak, aby byla zachycena klíčová podstata dramatu a bylo výrazně podpořeno jeho emocionální vyznění.

Jak dokládá korespondence mezi scénografem a ředitelstvím Národního divadla, potíže finančního charakteru doprovázely mnohé inscenace a s velkou pravděpodobností mohly být podstatou Heythumova ukončení spolupráce s Národním divadlem. Podobně tomu bylo i s Josefem Čapkem, ${ }^{69}$ který z finančních důvodů ukončil spolupráci s naší první scénou. Uvážíme-li, že během jednoho kalendářního roku vypravil Heythum ponejvíce čtyři inscenace a průměrný plat kancelářského úředníka byl ve dvacátých letech kolem 6000 Kč ročně a vyššího úředníka 20000 Kč ročně, pak odměna za jednu výpravu činící 500 až 1000 Kč byla poměrně nízká a rozhodně nestačila k obživě. Na druhou stranu je třeba připomenout, že mnozí scénografové vedle své divadelní práce vykonávali i jiná zaměstnání (např́íklad Vlastislav Hofman pracoval jako magistrátní úředník

68 Netýká se inscenace Podivná mezihra.

69 Bereme v úvahu informaci z Dostalova dopisu ze dne 29. prosince 1927 (Soukromá sbírka). 
pro urbanistický rozvoj Prahy). Poslední Heythumovy realizace v Národním divadlem se zároveň kryjí s přijetím velké architektonické zakázky na vytvoření projektu oficiálního československého výstavního pavilónu v Bruselu (1935-1936). ${ }^{70}$

\section{Soupis inscenací v ND, na nichž se A. Heythum scénograficky podílel71}

1. Rozum, Lev Nikolajevič, Andrejev,15. 5. 1924, režie Jaroslav Hurt

2. Druhý břeh, Jaroslav Hilbert, ND Praha, 20. 11. 1924, režie Karel Dostal

3. Př́ršti Mesiášs, Henry Soumagne, ND Praha, 5. 1. 1925, režie Karel Dostal

4. Veselé ženy windsorské, W. Shakespeare, režie K. H. Hilar, květen 1925, nerealizováno

5. Farma pod jilmy, Eugene O'Neill, Praha, 3. 10. 1925, režie Karel Dostal

6. Hra o lásce a smrti, Romain Rolland, režie K. H. Hilar, 1925 nerealizováno

7. Zmatek, Darius Milhaud, ND, 21. 5. 1926, režie Ferdinand Pujman, choreografie Remislav Remislavský

8. Žebrácká opera, Bertold Brecht a Kurt Weill, režie K. H. Hilar, nerealizováno

9. Velký bůh Brown, Eugen O’Neill, 11. 2. 1928, režie Karel Dostal

10. Todo je outsider, Vilém Werner, 31. 8. 1929, režie Viktor Šulc

11. Irena, Jaroslav Hilbert, Praha, 2. 11. 1929, režie Karel Dostal

12. Podiuná mezihra, Eugen O'Neill, 3. 3. 1930, režie K. H. Hilar

13. Lásky hra osudná, bratři Čapkové, 15. 5. 1930, režie Jiří Frejka

14. Třidič štěrku, Jaroslav Hilbert, 18. 9. 1930, režie Karel Dostal

15. Pěst, Jaroslav Hilbert, 26. 11. 1930 režie K. H. Hilar

16. Láska a umění, Benn W. Levy, 22. 10. 1930, režie Karel Dostal

17. Kupec benátský, W. Shakespeare, 16. 1. 1931, režie Karel Dostal

18. Rychlebové, Emil Synek, 29. 4. 1931, režie Viktor Šulc

19. Jaro národů, Adolf Nowaczyński, 19. 6. 1931, režie Karel Dostal

20. Slabé pohlaví, Edouard Bourdet, 20. 1. 1932, režie Vojta Novák

21. Let královny, Jaroslav Hilbert, 31. 10. 1932, režie Vojta Novák

22. Před slunce západem, Gerhart Hauptmann, 28. 2. 1933, na plakátu uveden jako scénograf Václav Gottlieb

23. Děti naši doby, Robert Adolf Stemmle, 20. 4. 1933, režie Karel Dostal

24. Aladin, Jan Klokoč, 9. 12. 1933, režie Karel Dostal

25. Záhadný př́pad, Edward Wooll, 14. 9. 1934, režie Vojta Novák

26. Druhý břeh, Jaroslav Hilbert, 28. 6. 1935, režie Karel Dostal

27. A $t$ žije divadlo, Henri-René Lenormand, 6. 12. 1935, režie Karel Dostal

28. Milionářka, George Bernard Shaw, 17. 1. 1936, režie Karel Dostal

29. Záríivá chvile, Keith Winter, 20. 3. 1936, režie Karel Dostal

70 Projekt pro pavilón využívající dřevěné konstrukce je uchován ve sbírce Národní galerie (NG AP 1688).

71 Uvádím soupis inscenací, které Heythum dovedl na jevišti Národního divadla k premiéře (míněno organizačně náležející k Národnímu divadlu, tedy i Stavovského, studiové scéně), i ty, na kterých spolupracoval, ale nakonec nebyly realizovány. 
30. Tančici safír (Isadora Duncanová), Ervín Neumann, 7. 9. 1936, režie Vojta Novák

31. Továrnik Dodsworth, Sidney Howyrd, Sinclair Lewis, 7. 12. 1936, režie Vojta Novák

32. Nikotina, Vítězslav Novák, 20. 3. 1937, choreografie Jelizavety Nikolskét2

\section{Bibliografie}

-A.V.- 1933. Aladin. Pražské noviny (12. 12. 1933).

DURYCH, Jaroslav. 1930. Antonín Heythum, Hrob Jiř́ho Wolkera. Praha: Václav Petr, soukromý tisk Č. 118, 1930.

HEYTHUM, Antonin. 1937. Le CrépusculeduThéatre, fourdesigns. TheatreArts 21 (listopad 1937): 11: 903-904.

HEYTHUM, Antonín. 2018. Antonín Heythum: scénograf, architekt, designér: Galerie moderního uméni v Roudnici nad Labem 20.9.-25.11.2018. Roudnice nad Labem: Galerie moderního umění, 2018.

KONRÁD, Edmond. 1930. Třidič štěrku. Národni osvobozeni 7 (1930): 259: 4.

ENGELMÜLLER, Karel. 1933. Aladin. Národni politika Praha (12. 12. 1933).

KOUBSKÁ, Vlasta. 2018. Scenographer Antonín Heythum and his work in the US: the case of King Lear. Theatralia 21 (2018): 2: 38-63.

Národní Muzeum, D 24218-24332.

Národní galerie. Sbírka architektury. AP 602.

Obrazová př́loha. Právo Lidu 11. 10. 1925: 3.

RUTTE, Miroslav. 1933. Aladin, aneb diskuse o hospodářské krisi. Národní listy (12. 12. 1933).

-sjc- 1933. Pohádka v zlých časech. Lidové listy (13. 12. 1933).

Soukromá sbírka. Majitelé si nepřejí bližší specifikaci.

SVRŠEK, Jaroslav. 1924. Music-Hally. Brno: Pasmo 5/6, Brno: U.S. Devětsil, 1924.

ŠVEHLA, Jaroslav. 1971. Heythumova výprava Lenormandovy hry At žije divadlo. Interscaena 3 (1971): I: 54.

TETIVA, Vlastimil a Vlasta KOUBSKÁ. 2012. František Muzika. Praha: Gallery, 2012.

72 Podle soupisu inscenací, který byl vyhotoven na základě dostupných archiválií, je nyní celkový počet inscenací, na nichž se podílel Antonín Heythum jako scénograf, 88 na našem území a 2 inscenace v USA. 


\section{doc. Vlasta Koubská}

Katedra scénografie,

Divadelní fakulta Akademie múzických umění,

Karlova 26, 11665 Praha 1, Česká republika

vlasta.koubska@damu.cz

Vlasta Koubská působí na Katedře scénografie Divadelní fakulty Akademie múzických umění v Praze. Dřive pracovala jako kurátorka a vedoucí Divadelního oddělení Národního muzea v Praze. Ve svém výzkumu se zabývá především českou avantgardní scénografií 20. a 30. let 20. století (F. Tröster, F. Zelenka, J. Čapek, B. Feuerstein, F. Muzika, V. Hofman, A. V. Hrska, F. Tichý, J. Malina, O. Schindler, J. Zbořilová a další). Je autorkou a spoluautorkou mnoha publikací.

Vlasta Koubská works at the Department of Scenography at the Academy of Performing Arts in Prague. Formerly, she was employed as a curator and manager of the Theatre Department at the National Museum in Prague. She mainly focuses on Czech avant-garde stage directions of 1920s and 1930s (F. Tröster, F. Zelenka, J. Čapek, B. Feuerstein, F. Muzika, V. Hofman, A. V. Hrska, F. Tichý, J. Malina, O. Schindler, J. Zbořilová and others) in her research. She is the author and co-author of a number of publications. 